\title{
APT Cooling Water Supply Make-up Trade Study, Revision 1
}

by

R. W. Reynolds

Westinghouse Savannah River Company

Savannah River Site

Aiken, South Carolina 29808

R. Hink
RECORDS ADMINISTRATION

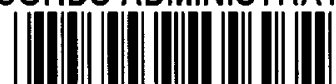

R. Hink

A document prepared for PUBLIC READING ROOM - ACCELERATOR PRODUCTION OF TRITIUM ENVIRONMENTAL IMPACT STATEMENT REFERENCES at , , from - .

DOE Contract No. DE-AC09-96SR18500

This paper was prepared in connection with work done under the above contract number with the U.S. Department of Energy. By acceptance of this paper, the publisher and/or recipient acknowledges the U.S. Government's right to retain a nonexclusive, royalty-free license in and to any copyright covering this paper, along with the right to reproduce and to authorize others to reproduce all or part of the copyrighted paper. 


\section{DISCLAMMER}

This report was prepared as an account of work sponsored by an agency of the United States Government. Neither the United States Government nor any agency thereof, nor any of their employees, makes any warranty, express or implied, or assumes any legal liability or responsibility for the accuracy, completeness, or usefulness of any information, apparatus, product, or process disclosed, or represents that its use would not infringe privately owned rights. Reference herein to any specific commercial product, process, or service by trade name, trademark, manufacturer, or otherwise does not necessarily constitute or imply its endorsement, recommendation, or favoring by the United States Government or any agency thereof. The views and opinions of authors expressed herein do not necessarily state or reflect those of the United States Government or any agency thereof.

This report has been reproduced directly from the best available copy.

Available to DOE and DOE contractors from the Office of Scientific and Technical Information, P.O. Box 62, Oak Ridge, TN 37831; prices available from (615) 576-8401.

Available to the public from the National Technical Information Service, U.S. Department of Commerce, 5285 Port Royal Road, Springfield, VA 22161. 


\section{APT}

Cooling Water Supply Make-up

\section{Trade Study}

Revision (1)

August 8, 1996 


\title{
APT Cooling Water Supply/Make-up Trade Study
}

\author{
Revision (1)
}

Date:

Prepared By:
August 8, 1996

Accelerator Production of Tritium, Balance of Plant, Conceptual Design Plant Systens Team (Steve Cruz/Ron Hink)

Approved By :- 


\section{APT Cooling Water Supply/Make-up Trade Study}

Objectives:

In the conceptual design of the APT cooling water system, several options exist for the design of the system(s) which serve as the ultimate heat sink. There are basically two approaches which are being considered for APT. The first approach involves the use of cooling towers at the APT site and providing makeup water to account for evaporative losses and blowdown. The second approach involves the use of heat exchangers at the APT and a larger water supply to remove the heat from the heat exchangers and transfer it directly to the ultimate heat sink, the Savannah River via PAR pond or the atmosphere through the K Area natural draft cooling tower.

It is not cost effective or desirable to proceed with the conceptual design without identifying specifically how the heat is to be removed from APT and transmitted to an ultimate heat sink. Thus, this trade study will evaluate several variations of the above methodologies.

2.0 Scope:

This study will evaluate alternative methods of providing an ultimate heat $\sin k \mathrm{t} n$ the APT. Specifically, either cooling towers with a source of makeup water, or a once through river water cooling system utilizing PAR pond for the heated effluent will be evaluated. This study will consider APT sites $\# 2$ and $\# 8$ currently being evaluated for selection (Reference attachment 9.4). All cost and technical discussion is based on Site\#2 with a discussion of the relation to Site $\# 8$ provided in Section 6.0. Utilization of cooling towers at the APT site and a supply of makeup water from the River Water system (identified as Alternative 1 herein) is the basis for the APT CDR estimate, therefore, it will be the base case for this study. Thus, no cost is presented for Alternative \#1, and the other alternatives present a cost delta relative to the base cost.

All alternatives will include the structures and equipment that form the portion of the heat removal system that extends from the cooling or makeup water source through the tertiary cooling loops to the APT secondary cooling loops up to the primary heat exchangers or chillers. Piping costs are included up to the general location of APT. The general intra-area pipe routing is considered equivalent for all options. Blowdown is considered in every case. The cost differential between each alternative's control system is not considered significant and therefore has not been included in this evaluation. Additionally, none of the alternatives include surge tanks for flow control. Although it is probable that additional provisions for flow control will be required, this requirement would effect all alternatives and is not considered in this evaluation 


\section{APT Cooling Water Supply/Make-up Trade Study}

All alternatives will utilize existing SRS systems and structures where possible. Specific assumptions related to each alternative are identified in Section 5.0. This study will rank all alternatives on direct equipment costs, operating and maintenance costs, and permitting risks.

3.0 Alternatives:

Several alternative methods of providing the process cooling water are described as follows:

1. River Water Makeup: Supply makeup water from the existing river water system (originally used to supply cooling water makeup to the reactors) to the APT mechanical draft cooling towers. Heated effluent is discharged to the atmosphere and continuos blowdown is directed to PAR Pond.

2. River Water Once Through: Provide heat exchangers at the APT site with cooling water supplied from the existing river water system using either the 681-1G or 681-3G pump house. Heated effluent and continuos blowdown is directed to PAR Pond.

3. Well Field Makeup: Supply makeup water from a new well field to APT mechanical draft cooling towers. Heated effluent is discharged to the atmosphere and continuos blowdown is directed to PAR Pond.

4. K Area Cooling Tower: Use the $\mathrm{K}$ Area cooling tower to remove heat from the cooling water. This alternative makes use of portions of the existing river water system in order to minimize new runs of large diameter concrete pipe. Heated effluent is discharged to the atmosphere and continuos blowdown is directed to the $\mathrm{K}$-area outfall.

All alternatives have been simplified to focus on the primary cost drivers. A judicious effort has been made to maintain a fair comparison between each alternative.

Several variations on the above alternatives exist, and were not specifically evaluated. These include:

Supply cooling water to the APT heat exchangers from the existing river water system using 681-6G pump house at PAR pond. This option was not evaluated due to the fact that the $681-6 \mathrm{G}$ pump house has not been maintained, and thus the equipment condition was suspect. The cost and feasibility associated with this option is essentially identical to Alternative 2 above. The primary difference would be the additional cost in restoring the 


\section{APT Cooling Water Supply/Make-up Trade Study}

pump house, and the lower operating cost due to lower horse power pumps.

Make use of a new cooling pond to remove heat from the APT heat exchangers. This option was not evaluated due to the fact that preliminary estimates of the retention pond size indicated that the pond would have to be extremely large to remove the required heat. Thus, this option was not considered technically feasible.

* A once through cooling system utilizing well water supply. This alternative is not considered feasible as the number of wells required to meet the demand would be cost prohibitive and the permitting risk associated with this production rate was considered to be extremely high.

These alternatives cover the most common and frequently used types of systems. Other alternatives or variations may exist, but were not considered in this report.

Alternatives are evaluated on technical feasibility, direct capital costs, operating and maintainability costs, and permitting risks. Technical feasibility is evaluated on a go/no go basis, and all of the alternatives evaluated herein are technically feasible in that they can provide the required cooling given that the proper equipment (either new or modified) is in place. The remaining criteria will be assigned a numerical value or score based on a performance scale of 0 to 5 such that 3 is the rating of the base alternative (Alternative 2 ) with higher numbers increasingly better than the base and lower numbers increasingly worse. For the purpose of this study the criteria were weighted as: direct capital cost $-20 \%$, operating and maintainability costs $-30 \%$, and permitting risk $-50 \%$.

5.0 Evaluation of Alternatives for APT Site \#2:

\subsection{River Water Makeup (Alternative \#1)}

\section{Description of System:}

This scenario relies on mechanical draft cooling towers as the primary means of transferring heat from APT to the atmosphere. Makeup water is required to account for evaporative losses and continuous blowdown. Preliminary calculations indicate that approximately $6000 \mathrm{gpm}$ of makeup water will satisfy the peak demand for APT. This $6000 \mathrm{gpm}$ could be supplied using a portion of the existing river water system. The modified system would consist of 2 replacement pumps (one is utilized as a spare) in 


\section{APT Cooling Water Supply/Make-up Trade Study}

either the 681-1G or the 681-3G pump house, use of the existing " $R$ Normal" river water header, and the addition of approximately $18,000 \mathrm{ft}$ of 18 " PVC pipe. Additionally, approximately $24,000 \mathrm{ft}$ of 10 " PVC pipe would be required along with pumps for continuous blowdown to PAR pond. Figure 1 shows a rough schematic of the proposed system.

Figure 1: 6000 gpm Makeup from RWS

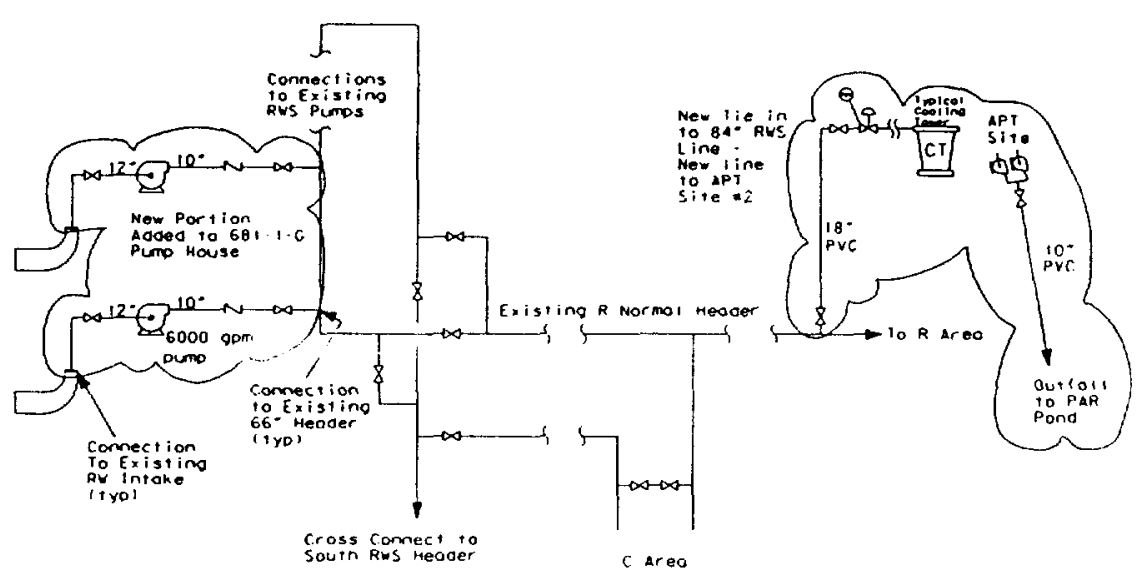

The specific equipment and modifications required for this alternative include:

- Remove 2 existing RWS pumps in the 681-1-G or 681-3G pump house.

- Add two 12" Schedule 40 carbon steel pump suction lines, each with a 12 " suction isolation gate valve.

- Add 2 new and smaller river water centrifugal pumps (one to be utilized as a spare). These pumps should be rated at 6000 gpm @ $420 \mathrm{ft}$ TDH.

- Add two 10" Schedule 40 carbon steel pump discharge lines, each with a 10 " check valve and a 10" discharge isolation gate valve, and a tie in to the existing 66" header in 681-1-G.

- Add 18" carbon steel tie in connection to existing 84" RWS header between $\mathrm{C}$ Area and $\mathrm{H}$ Area including an 18" isolation gate valve.

- Add 18,000 ft of 18" PVC pipe - bell and spigot type.

- Add 18" carbon steel line to connect to the APT cooling tower. The line should include an 18" isolation gate valve as well as a flow control valves at the APT site cooling towers

- Add 24,000 ft of 10" PVC pipe - bell and spigot type and pumps for continuous blowdown to PAR Pond 


\section{APT Cooling Water Supply/Make-up Trade Study}

Significant Assumptions:

- It is assumed that the existing outfall structure at PAR pond may be utilized. Site Services Engineering has indicated that the outfall is in good condition, and was sized to handle in excess of 200,000 gpm.

- The piping lengths are based on a rough straight line estimate from the river water system to the APT site.

- The existing river water intake structure can be permitted for use by APT.

- It is assumed that the cooling tower basins have adequate inlet surge capacity for system flow stability. No additional cooling water capacity is provided for pump start-up or other system operational transients.

- One spare supply header pump has been considered sufficient to maintain the required system operability requirements. Additional pumps may be required but were not considered in this evaluation.

Advantages:

This type of system is very common and provides a stable and predictable source of makeup water.

The existing river water system is permitted to remove significantly more water than the $6000 \mathrm{gpm}$ required for makeup to APT, and the ability to outfall to PAR pond has been evaluated and found acceptable in Reference 9.2. Also, the required equipment is common and should be readily available.

\section{Disadvantages:}

A possible disadvantage of this system is that the existing river water system is beyond it's original design life, and to continue to rely on the integrity of the piping and components could be a concern. However, this has been addressed in Reference 9.1 (River Water System Shutdown: Layup Requirements (U), EFR-ENG-950067) which concluded that the river water system is in exceptional condition and should be usable for many years to come. The only real disadvantage of this system is that there is a potential for stagnation or biological fouling problems to result from the very low water velocity in the large river water pipes. This results from the fact that the existing river water system was designed for flows on the order of $150,000 \mathrm{gpm}$. There is only limited experience to predict how the pipe will respond to the very lows flows required by APT. The fouling may be eliminated by chemical treatment at the river water pump house. 


\section{APT Cooling Water Supply/Make-up Trade Study}

It is not certain at this time how favorable this option is for SCDHEC permitting. Should the intake structure require a new permit, the facility may also be required to upgrade to new design standards.

Cost:

The capital cost of the above described modifications and additions are defined as the base case for evaluation of all alternatives. Other study case costs will be reflected as cost adjustments to this base cost.

5.2 River Water Once Through (Alternative \#2)

Description of System:

This scenario relies on heat exchangers (used in lieu of cooling towers) as the primary means of transferring heat from APT to the river water.

Preliminary calculations indicate that approximately $125,000 \mathrm{gpm}$ supply of cooling water to the heat exchangers will satisfy the maximum heat loading for the APT. This $125,000 \mathrm{gpm}$ could be supplied using a portion of the existing river water system. The modified system would utilize the existing pumps in either the $681-1 \mathrm{G}$ or the $681-3 \mathrm{G}$ pump house, use the existing "R-Normal" river water header, and the addition of approximately 18,000 $\mathrm{ft}$ of 128 " concrete pipe connecting the river water system to the heat exchangers at the APT site. Additionally, four new pumps and approximately $24,000 \mathrm{ft}$ of 100 " concrete pipe would be required for discharge to PAR pond. Figure 2 shows a schematic of the proposed system.
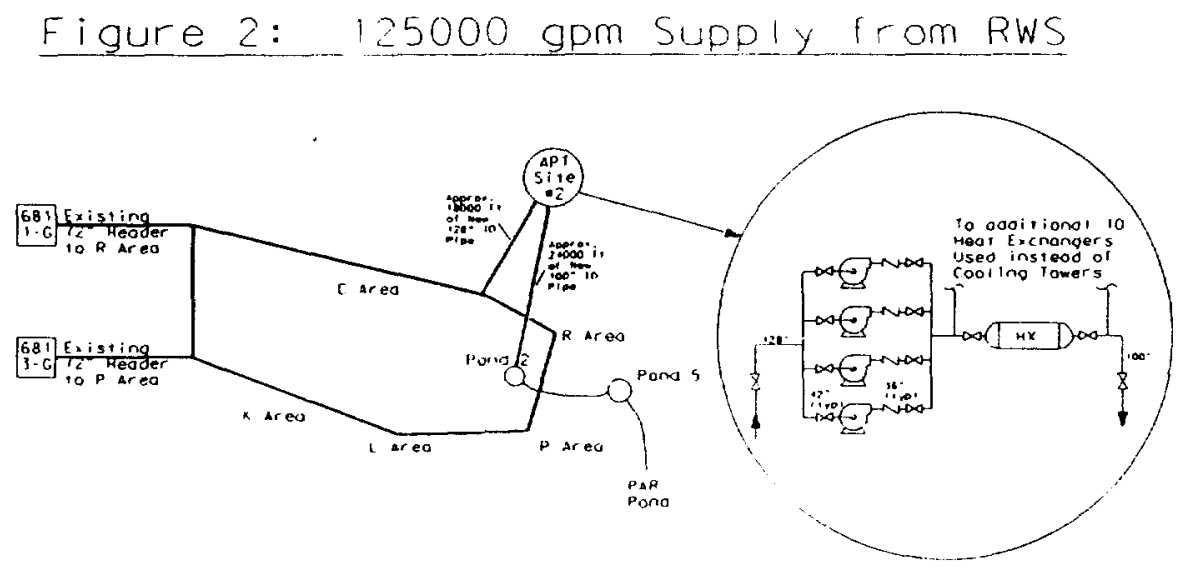


\section{APT Cooling Water Supply/Make-up Trade Study}

The specific equipment and modifications required for this alternative include:

- Add approximately 18,000 linear $\mathrm{ft}$ of 128 " internal diameter concrete pipe rated at roughly 80 psig to connect from "R Normal Header" to APT Site \#2. This line should include 2 isolation valves (one at either end).

- Add four 42 " Schedule 10 carbon steel pump suction lines, each with a 42 " suction isolation gate valve.

- Add four new pumps rated at 50,000 gpm at $80 \mathrm{ft} \mathrm{TDH}$.

- Add four 36" Schedule 10 carbon steel pump discharge lince, art with a 36 " check valve and a 36 " discharge isolation gate valve.

- Add approximately 24,000 linear $\mathrm{ft}$ of 100 " internal diameter concrete pipe rated at 80 psig to connect APT Site \#2 to Pond 2 which will outfall into PAR Pond. This line should include 2 isolation valves (one at either end).

- Eliminate the cooling station cooling towers.

- Replace the existing primary heat exchangers with heat excliangers designed for the once through cooling system operation.

\section{Significant Assumptions:}

- It is assumed that the use of the existing outfall structure at PAR pond may be utilized. Site Services Engineering has indicated that. the outfall is in good condition, and was sized to handle in excess of $200,000 \mathrm{gpm}$.

- The piping lengths are based on a rough straight line estimate from the river water system to the APT site.

- It is assumed that the river water system may be operated close to its design capacity for the life of the APT. This may be possible given the good condition of the pipe as reported in Reference 9.1.

- It is assumed that the existing river water pumps can produce sufficient head to supply the flow requirements of APT. Significant head loss can be expected in the existing river water lines and the new lines to APT. Detailed head loss data for the existing lines is not available, and this may affect the usability of the river water pumps though some margin appears to exist based on preliminary analysis. 


\section{APT Cooling Water Supply/Make-up Trade Study}

- It is assumed that no inlet flow surge capacity is required for system flow stability. No additional cooling water capacity is provided for pump start-up or other system operational transients. Proper system control may require the addition of a surge tank but these costs have not been included in this evaluation.

- One spare supply header pump has been considered sufficient to maintain the required system operability requirements. Additional pumps may be required but were not considered in this evaluation.

- The control system required by this alternative is assumed to be of equivalent cost and complexity to other alternatives being evaluated. This system, in fact, may require a more complex control system due to the complexity and size of the pumping system.

- The once through heat exchangers are assumed to be of equal cost when compared to the base case primary heat exchangers. Further analysis is requried to determine the actual surface area and flow rates requried. This assumptions should provide a reasonalble basis for order of magnitude cost comparisons

\section{Advantages:}

This type of system also is very common and provides a very stable and predictable source of makeup water.

The existing river water system is permitted to remove significantly more water than the $125,000 \mathrm{gpm}$ required for APT, and the ability to outfall to PAR pond has been evaluated and found acceptable in Reference 9.2.

Disadvantages:

A possible disadvantage of this system is that the existing river water system is beyond its original design life, and to continue to rely on the integrity of the pumps, piping, and components could be a concern. However, this has been addressed in Reference 9.1 (River Water System Shutdown: Lay-up Requirements (U), EFR-ENG-950067) which concluded that the river water system is in exceptional condition and should be usable for many years to come. One real disadvantage of this system is that it requires special order equipment such as very large diameter pipe, large pumps, and many large heat exchangers. There is also a substantial and difficult installation associated with the long runs of large diameter pipe. Additionally, the electrical power requirements are large due to the energy required to move 125,000 gpm from the river to the APT site ( 10MW). 


\section{APT Cooling Water Supply/Make-up Trade Study}

It is not certain at this time how favorable this option is for SCDHEC permitting. Should the intake structure require a new permit, the facility may also be required to upgrade to new design standards.

Cost:

The additional capital cost of the above described modifications and additions relative to Alternative 1 has been estimated at $\$ 21.2 \mathrm{M}$. (Referenced the attached cost estimate)

The estimated costs of this option has been credited for the elimination of the cooling towers.

\subsection{Well Field Makeup (Alternative \#3)}

\section{Description of System:}

This scenario relies on mechanical draft cooling towers as the primary means of transferring heat from APT to the atmosphere. Makeup water is required to account for evaporative losses and continuous blowdown. Preliminary calculations indicate that approximately $6000 \mathrm{gpm}$ of makels water will satisfy the maximum heat load conditions for APT. This 6000 gpm could be supplied using a well field located as close to the APT site as practical. Current estimates indicate that this system would include 18 production wells rated for approximately $500 \mathrm{gpm}$ each, and a distribution system to deliver the water to the APT site. Figure 3 shows a schenatic of the proposed system. Location of a well field has not been determined and thus assumptions are used to estimate piping lengths required.

\section{Figure 3: 6000 gpm Makeup from Wel is}
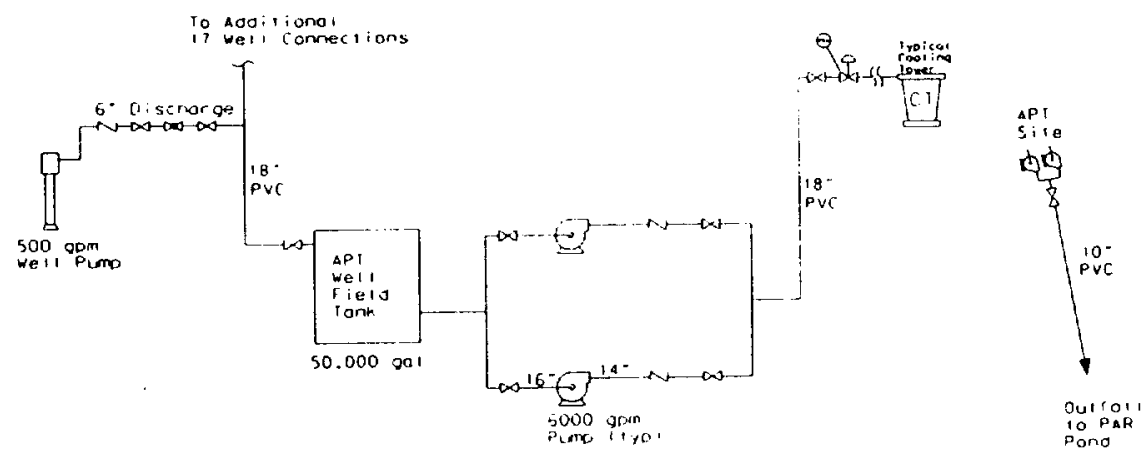


\section{APT Cooling Water Supply/Make-up Trade Study}

The specific equipment and modifications required for this alternative include:

- Drill 18 production wells rated for $500 \mathrm{gpm}$

- Add 18 well pumps rated at $500 \mathrm{gpm}$ at approximately $50 \mathrm{ft} \mathrm{TDH}$.

- For each well add $10 \mathrm{ft}$ of 6" Schedule 10 stainless steel pipe to include two 6" isolation gate valves, one 6" control valve, and one flow measuring device.

- For each well add $100 \mathrm{ft}$ of 6" PVC pipe

- Add $1000 \mathrm{ft}$ of 18 " PVC pipe to connect all wells to well field tank.

- One well field tank - 50,000 gallon.

- Add two 16" carbon steel pump suction lines, each with a 16" suction isolation valve.

- Add 2 centrifugal pumps. These pumps should be rated at 6000 gpm@100 ft TDH (example Goulds model 3415-DV 14x16-18).

- Add two 14" carbon steel pump discharge lines, each with a 14" check valve and a 14" discharge isolation valve.

- $5000 \mathrm{ft}$ of 18 " PVC pipe - bell and spigot type (example J-M Pipe, Big Blue large diameter PVC pressure pipe)

- Add 24,000 ft of 10" PVC pipe - bell and spigot type (example J-M Pipe, Big Blue large diameter PVC pressure pipe) for continuous blowdown to PAR Pond.

\section{Sinificant Assumptions:}

- It is assumed that the use of the existing outfall structure into PAR pond may be used. Site Services Engineering has indicated that the outfall is in good condition, and was sized to handle in excess of $200,000 \mathrm{gpm}$.

- The piping lengths are based on assumptions that the wells are located within approximately $500 \mathrm{ft}$ of one another, and that the well field is not more than $5000 \mathrm{ft}$ from the APT site.

- It is assumed that production wells can be developed to provide the required 500 gpin per well. Estimates from the geotechnical group indicate that this is the maximum flow that can be expected from a deep well at SRS (Reference 9.3).

- It is assumed that 12 wells is sufficient to provide the required 6000 gpm. An additional 6 wells are included in the estimate to account for any problems associated with the wells (e.g. degradation, plugging, etc.). This provides a reasonable degree of conservatism as the $6000 \mathrm{gpm}$ requirement is a peak load requirement. 


\section{APT Cooling Water Supply/Make-up Trade Study}

- It is assumed that ground water use permits will be granted by SCDHEC and that ground water flow characteristics will not adversely effect the aquifer.

- A 50,000 gallon collection/surge tank was selected to provide inlet surge capacity for system flow stability. It is assumed that this capacity is adequate to accommodate well pump start-up and other system operational transients.

- No costs have been included for well controls or field housing of instrumentation and equipment. It is not believed that these costs are of a magnitude to significantly affect the evaluation's results.

\section{Advantages:}

This type of system is very common and provides a reasonably stable source of makeup water. Also, the required equipment is common and should be readily available.

\section{Disadvantages:}

A significant disadvantage of this system is that permitting is perceived to be difficult based on preliminary evaluations by the site geotechnical services department (Reference 9.3). This is due to the evaluation that removal of $6000 \mathrm{gpm}$ may result in the SRS seriously impacting the affected aquifer system.

\section{Cost:}

The additional cost of the above described modifications and additions relative to Alternative 1 has been estimated at $\$ 1.1 \mathrm{M}$. (Reference the attached cost estimate)

\subsection{K Area Cooling Tower (Alternative \#4)}

\section{Description of System:}

This scenario relies on heat exchangers (used in lieu of cooling towers) as the primary means of transferring heat from the APT site. The heat is dissipated to the atmosphere using the K Area (natural draft) cooling tower. Preliminary calculations indicate that approximately $125,000 \mathrm{gpm}$ supply of cooling water to the heat exchangers will satisfy the maximum heat load for APT. This 125,000 gpm could be supplied using the existing K Area Cooling Tower pumps and approximately 40,000 ft of 80 " concrete pipe. The return leg would require additional pumps, approximately $18,000 \mathrm{ft}$ of 80 " concrete pipe, and would make use of a portion of the existing river water system to minimize the amount of new pipe required. Additionally, a source of makeup water would need to provide 


\section{APT Cooling Water Supply/Make-up Trade Study}

approximately $6000 \mathrm{gpm}$ to account for evaporative losses and continuous blowdown. Figure 4 shows a rough schematic of the proposed system.

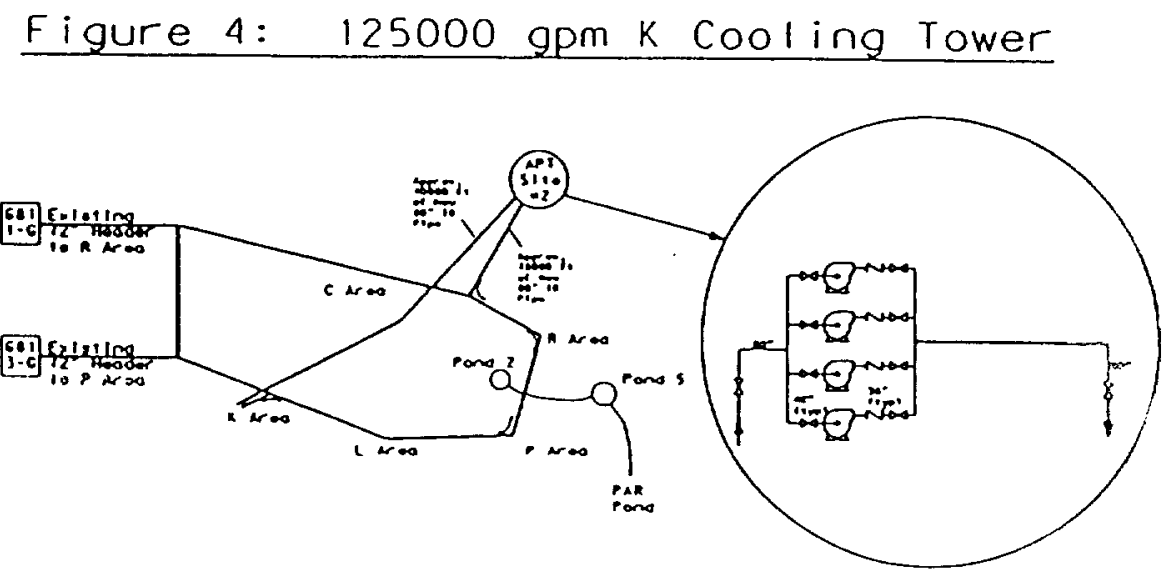

The specific equipment and modifications required for this alternative include:

- Add approximately 40,000 linear $\mathrm{ft}$ of 80" internal diameter concrete pipe rated at roughly 125 psig to connect from $\mathrm{K}$ Area Cooling Tower to APT Site \#2. This line should include 2 isolation valves (one at either end).

- Add four 42" Schedule 10 carbon steel pump suction lines, each with a 42 " suction isolation gate valve.

- Add four new pumps rated at $50,000 \mathrm{gpm}$ at $130 \mathrm{ft}$ TDH (erample Goulds model 3420 36×42-48 High Q).

- Add four 36" Schedule 10 carbon steel pump discharge lines, each with a 36 " check valve and a 36" discharge isolation gate vaive.

- Add piping and valves associated with the heat exchangers that will serve as the ultimate heat sink for APT

- Add approximately 18,000 linear $f t$ of 80 " internal diameter concrete pipe rated at roughly 100 psig to connect APT Site \#2 to the "R Normal Header" which will then deliver flow back to K Area Cooling Tower. This new line should include 2 isolation valves (one at either end of the new portion) if possible.

- Modify R Area and P Area lines to allow flow to K Area. This should require approximately $300 \mathrm{ft}$ of $78^{\prime \prime} \mathrm{W}$ concrete pipe. 


\section{APT Cooling Water Supply/Make-up Trade Study}

- Tie in to 84" ID "P Normal Header" to branch off to K Area Cooling Tower for return line. This should require approximately $300 \mathrm{ft}$ of 80 " ID concrete pipe.

- Provide makeup water supply using a method similar to Alternative 1 except routing the makeup water flow to the $\mathrm{K}$ Area Cooling Tower which would require only a few hundred feet of 18" PVC pipe in lieu of the $18,000 \mathrm{ft}$ required by Alternative 1. If permitting does not allow discharge to the $\mathrm{K}$-area outfall, additional cost will be incurred as a result of routing to an alternate outfall such as PAR Pond.

- Eliminate the cooling towers at the APT site cooling stations.

\section{Significant Assumptions:}

- It is assumed that the existing $\mathrm{K}$ Area outfall may be utilized for system blowdown.

- The piping lengths are based on a rough straight line estimate from the river water system to the APT site.

- It is assumed that portions of the river water system may be operated close to its design capacity for the life of the APT. This may be possible given the good condition that the pipe is reported to be in Reference 9.1.

- It is assumed that the existing K Area Cooling Tower pumps can produce sufficient head to supply the flow requirements of APT, and that the pumps are in usable condition. There were known problems associated with these pumps, of which most are reported have been resolved.

- $\mathrm{K}$-cooling tower is assumed to be in tact and in good condition. No costs have been included for any modification, repairs, or upgrades to the structure. Although some portions of the cooling tower system have been removed for use elsewhere, it is not believed that the resulting equipment repair/replacement costs will significantly affect the results of this evaluation.

- It is assumed for this evaluation that the cooling tower will function in all modes of APT operation. It has not been determined if the conditions of operation are adequate to induce a natural draft in the tower, nor has it been determined that a draft would be required to provide the required cooling. A detailed engineering study is required to determine the technical adequacy of the cooling tower. 


\title{
APT Cooling Water Supply/Make-up Trade Study
}

\begin{abstract}
Advantages:
This type of system also is very common and provides a stable and predictable source of makeup water. The existing river water system is permitted to remove significantly more water than the $6,000 \mathrm{gpm}$ required for APT makeup. The ability to outfall at $\mathrm{K}$ Area does not appear to be a problem as the outfall is currently permitted for a larger flow.
\end{abstract}

\section{Disadvantages:}

A possible disadvantage of this system is that the existing river water system is beyond its original design life, and to continue to rely on the integrity of the piping and components could be a concern. However, this has been addressed in Reference 9.1 (River Water System Shutdown: Layup Requirements (U), EFR-ENG-950067) which concluded that the river water system is in exceptional condition and should be usable for many years to come. One real disadvantage of this system is that it requires special order equipment such as very large diameter pipe, large pumps, and many large heat exchangers. There is also a substantial and difficult installation associated with the long runs of large diameter pipe.

Additionally, the electrical power requirements are large due to the energy required to move $125,000 \mathrm{gpm}$ from the $\mathrm{K}$ Area to the APT site and back.

It is not certain at this time how favorable this option is for SCDHEC permitting. The cooling tower facilities may be required to upgrade to new design standards prior to permit approval.

Cost:

The additional capital cost of the above described modifications and additions relative to Alternative 1 has been estimated at $\$ 15.7 \mathrm{M}$.

(Reference the attached cost estimate)

\subsection{Evaluation of Alternatives for APT Site \#8:}

The alternatives for APT Site \#8 are identical to those for APT Site \#2. The advantages and disadvantages are the same; however, the costs associated with each alternative may fluctuate due to the different site location. Specifically, APT Site \#8 is further from the existing River Water system lines than APT Site \#2. This will result in higher costs for Alternatives 1, 2, and 4 . Alternative 3 (Well Field Makeup) may or may not be affected dependent on where the actual well fields can be located for the respective sites. 


\section{APT Cooling Water Supply/Make-up Trade Study}

7.0 Assignment of Scores:

\begin{tabular}{|l|c|l|}
\hline \multicolumn{3}{|c|}{ Assignment of Scores for Capital Costs } \\
\hline \multicolumn{1}{|c|}{ Alternative } & Score & \multicolumn{1}{c|}{ Basis } \\
\hline 1. River Water Make-up & 3 & Base Alternative \\
\hline 2. River Water Once Thru & 1 & $\begin{array}{l}\text { Significantly more expensive than the base } \\
\text { case (by \$21.2M) }\end{array}$ \\
\hline 3. Well Field Make-up & 3 & Expense is only marginally higher (by \$1.1M) \\
\hline 4. K-Cooling Tower & 1 & $\begin{array}{l}\text { More expensive than the base case (by } \\
\text { \$15.7M) }\end{array}$ \\
\hline
\end{tabular}

\begin{tabular}{|l|c|l|}
\hline \multicolumn{3}{|c|}{ Assignment of Scores for Operating and Maintenance Costs } \\
\hline \multicolumn{1}{|c|}{ Alternative } & Score & \multicolumn{1}{|c|}{ Basis } \\
\hline 1. River Water Make-up & 3 & Base Alternative \\
\hline 2. River Water Once Thru & 1 & $\begin{array}{l}\text { Old pumps require more maintenance. Very } \\
\text { high operating costs are expected due to large } \\
\text { power requirements }\end{array}$ \\
\hline 4. K-Cooling Tower & 2 & $\begin{array}{l}\text { More expensive than the base case due to the } \\
\text { large number of wells to be maintained. }\end{array}$ \\
\hline & $\begin{array}{l}\text { More and larger pumps require additional } \\
\text { maintenance. Very high operating cosis due } \\
\text { to greater power requirements }\end{array}$ \\
\hline
\end{tabular}

\begin{tabular}{|l|c|l|}
\hline \multicolumn{3}{|c|}{ Assignment of Scores for Permitting Risk } \\
\hline \multicolumn{1}{|c|}{ Alternative } & Score & \multicolumn{1}{c|}{ Basis } \\
\hline 1. River Water Make-up & 3 & Base Alternative \\
\hline 2. River Water Once Thru & 2 & $\begin{array}{l}\text { Increased permitting risk due to large water } \\
\text { demand from the river. }\end{array}$ \\
\hline 3. Well Ficld Make-up & 1 & $\begin{array}{l}\text { Significant permitting risk due to large } \\
\text { demand on the Cretaceous aquifer }\end{array}$ \\
\hline 4. K-Cooling Tower & 2 & $\begin{array}{l}\text { Permitting risk associated with permitting the } \\
\text { cooling tower. }\end{array}$ \\
\hline
\end{tabular}




\section{APT Cooling Water Supply/Make-up Trade Study}

8.0 Conclusions:

While the descriptions and information presented above are not detailed, they do provide enough information to make a selection of an alternative based on the identified criteria. Clearly, the costs associated with running long lines of large diameter concrete pipe is not cost effective relative to providing makeup water where smaller diameter PVC pipe can be used. The following is a summary of all alternatives and their ranking:

\begin{tabular}{|l|c|c|c|c|c|}
\hline \multicolumn{1}{|c|}{ Criteria } & $\begin{array}{c}\text { Weighting } \\
\text { (\%) }\end{array}$ & $\begin{array}{c}\text { River } \\
\text { Water } \\
\text { Make-up }\end{array}$ & $\begin{array}{c}\text { River } \\
\text { Water } \\
\text { Once Thru }\end{array}$ & $\begin{array}{c}\text { Well Field } \\
\text { Make-up }\end{array}$ & $\begin{array}{c}\text { K-Cooling } \\
\text { Tower }\end{array}$ \\
\hline $\begin{array}{l}\text { Capital } \\
\text { Costs }\end{array}$ & 20 & 3 & 1 & 3 & 1 \\
\hline $\begin{array}{l}\text { Ops \& } \\
\text { Maint Costs }\end{array}$ & 30 & 3 & 1 & 2 & 2 \\
\hline $\begin{array}{l}\text { Permitting } \\
\text { Risks }\end{array}$ & 50 & 3 & 2 & 1 & 2 \\
\hline $\begin{array}{l}\text { Ranking } \\
\text { Factor }\end{array}$ & & 3 & 1.5 & 1.7 & 1.8 \\
\hline
\end{tabular}

Based on the above, Alternative 1: River Water Makeup is the favorable alternative. This alternative has the lowest cost, and no disadvantages that appear insurmountable

9.0 References:

9.1 River Water System Shutdown: Lay-up Requirements (U), EFR-ENG950067

9.2 Study on allowable temp of discharge to PAR pond

9.3 IOM from Dale E. Stephenson to Elizabeth Topp, "Preliminary Evaluation of Proposed Well Field for APT", dated 7 May 1996. (Attachment 1)

9.4 APT Siting Map (Attachment 2)

9.5 Trade Study Estimate (Attachment 3 
APT Cooling Water Supply/Make-up Trade Study

\section{Attachment (1)}

"Proposed Well Field for APT IOM"

[This page intentionally left blank] 


\section{INTER-OFFICE MEMORANDUM \\ WESTINGHOUSE SAVANNAH RIVER COMPANY}

7 May 1996

TO: Elizabeth G. Topp, 730-2B

FROM: Dale E. Stephenson, 730-2B

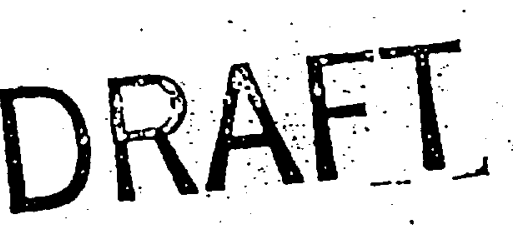

\section{PRELIMTNARY EVALUATION OF PROPOSED WELL FIELD FOR APT}

A very preliminary analysis of requirements for supplying groundwater at the rate of $6000 \mathrm{gpm}$ (gallons per minute) for the APT was made at the request of Jeff England. The assumption was made that the wells will pump from the Cretaceous aquifer and the $6000 \mathrm{gpm}$ is continuous. This equals $8.64 \times 10^{6} \mathrm{gpd}$ (gallons per day) total production to support the APT operation.

Most Dublin-Midville aquifer system production well drilled at SRS in recent years were designed to produce $500 \mathrm{gpm}$, even though a few in the early years could produce $1500 \mathrm{gpm}$ maximum. Assuming that any new wells will be designed to produce $500 \mathrm{gpm}$ a well field to supply 6000 gpm will require 12 well that will operate continuously. To provide backup a minimum of 24 weil should be constructed to supply groundwater for the operation of the ATP. To control the amount of drawdown to no more than approximately one-half the aquifer thickoss the wells should be placed one per acre. This will result in about 25 feet of drawdown at the mid-point between the wells. The last estimate of the cost of a production well that will produce $500 \mathrm{gpm}$ from the Dublin-Midville aquifer system was $\$ 500,000.00$ per well.

The concerns of this proposed well field to supply $6000 \mathrm{gpm}$ or $8.64 \mathrm{Mgpd}$ is that this will result in the SRS seriously impacting the aquifer system. Marine and Routt (1975) calculated the flux in the aquifer system at the SRS as at least $19.4 \mathrm{Mgpd}$ and maybe as high as $42 \mathrm{Mgpd}$. Hubbard et al (1988) calculated the groundwater flow through the Dublin-Midville system to be about $25 \mathrm{Mgpd}$ and Aadland et al (1996) estimate a value of $16 \mathrm{Mgpd}$ fir the flow through the system. As of 1993 the groundwater pumpage at SRS was $6.4 \mathrm{Mgpd}$ under normal operating conditions with this being mostly from the Dublin-Midville aquifer system. If the ATP requirements are added to the current groundwater use the SRS will be extracting about $15 \mathrm{Mgpd}$ from the aquifer systern which will be approaching the total flux within the system. If any other demands are placed on the system the SRS could start to mine the aquifer. For this rcason it is my opinion that obtaining a permit from the State will be difficult. 
APT Cooling Water Supply/Make-up Trade Study

\title{
Attachment (2)
}

\author{
APT Siting Map
}

[This page intentionally left blank] 


\title{
APT Cooling Water Supply/Make-up Trade Study
}

\section{Attachment (3)}

\author{
Trade Study Estimate
}

[This page intentionally left blank] 
FILE: APTCOOL

PROJeCT NAME: PRC,
ENGINEERING \& CONS UTION SERVICES DIVISION

SITE PROJLUT ESTIMATING

DETAIL LINE ITEMS
PAGE * 1

TIME: 08:35:58

DATE 09-Aug-1996

PRICING: PRE 95 OR POST 94 RATES

REPORT NAME: APT Detail WBS EXCEL. FORMAT

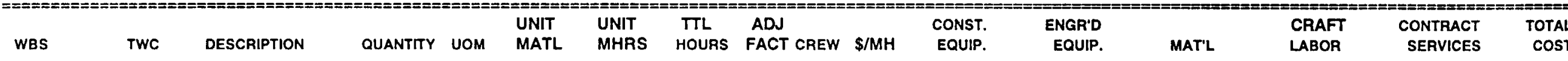

GROUP : NO APT GROUP IDENTIFIED

ACCOUNT CODE:

1940 REMOVE EXISTING RWS PUMPS $[25000$ GPM 3000

1310 INSTALL NEW RWS PUMPS [5000 GPM $300 \mathrm{HPI}$

4270 MOOIFY INLET CONN. - 46.* $36^{*} \times 1 / 4^{\prime}$ STEEL PLATE $[75$

$831736^{2} \times 12^{*}$ CS REDUCE

$831312^{\circ}$ PIPE, CS. STD

8313 12* ELL, 90

8313 12" FLANGE, WN, 150*

8714 12. GATE VALVE, FLG. CS

8313 12* BOLT.UP W/ B8G SET

$891212^{\circ}$ HYOROTEST

4569 12" PIPE - PRIME \& PAINT 2OLF

13 10" WELDOLET, CS [66' PIPE TIE-IN] - ALLOWANCE

8313 10" PIPE, CS, STD

8313 10 FLANGE, WN, 150*

$871410^{\circ}$ CHECK VALVE, FLG. CS

8714 10. GATE VALVE, FLG, CS

8313 10" BOLT.UP W/ B\&G SET

$865310^{\circ}$ PIPE, PVC

$891210^{\circ}$ HYDROTEST

$456910^{\circ}$ PIPE - PRIME \& PAINT $20 L F$

$394084^{\circ}$ CONCRETE PIPE, D\&R 8 THK CONCAETE $\left(10^{\circ}\right.$ TIE-IN]

$831518^{*}$ WELDOLET, CS [84" PIPE TIE-IN]

8315 18. PIPE, CS, STD

8315 18" FLANGE, WN, 150"

$031510^{\circ}$ ELL. 90

$871418^{\circ}$ GATE VALVE, FLG, CS

$871418^{\circ}$ FLOW CONTROL VALVE FLG, CS

$831318^{\circ}$ BOLT.UP W/B8G SET

$891218^{\circ}$ HYDROTEST

8654 19* PIPE, PVC, BIG BLUE

$824018^{\circ} \mathrm{ELL} .90 . \mathrm{MJ}$.
WBS 1.2.1.01

$0.00 \quad 940.000$

2.0EA $\quad 180000.00 \quad 180.000$

$2.0 \mathrm{EA}$

$2.0 \mathrm{EA}$

$20.0 \mathrm{LF}$

2.0 EA

$6.0 \mathrm{EA}$

$2.0 \mathrm{EA}$

$6.0 \mathrm{EA}$
$20.0 \mathrm{LF}$

$20.0 \mathrm{LF}$
$70.0 \mathrm{SF}$

2.0 EA

20.0 LF

$10.0 \mathrm{EA}$

$2.0 \mathrm{EA}$

$2.0 \mathrm{EA}$
$10.0 \mathrm{EA}$

10.0 EA

$24,000.0$ LF

20.0 LF

$15.0 \mathrm{SF}$

$1.0 \mathrm{LS}$

$1.0 \mathrm{EA}$

$20.0 \mathrm{LF}$

$7.0 \mathrm{EA}$

$2.0 \mathrm{EA}$

2.0 EA

$1.0 \mathrm{EA}$

$7.0 \mathrm{EA}$

$20.0 \mathrm{LF}$

$18,000.0 \mathrm{LF}$

18.0 EA

$30.00 \quad 3.500$

$\begin{array}{ll}12.20 & 0.220\end{array}$

$0.00 \quad 0.310$

$0.70 \quad 0.108$

$100.00 \quad 24.000$

$140.00 \quad 32.700$

$\begin{array}{ll}51.50 \quad 0.950 \\ 480.00 & 12.700\end{array}$

$480.00 \quad 12.700$

$490.00 \quad 20.500$

$12400.00 \quad 6.700$

$30000.00 \quad 15.000$

$68.00 \quad 6.600$

$\begin{array}{rr}0.00 & 0.510\end{array}$

660.00
SITE \#2, COOLING OPTION \#1
X01 17.60

$1,880 \quad 1.00$ SRSX01 17.60

$360 \quad 1.00$ SRSX01 17.60

231.00 sqsxor 17.60

$\begin{array}{lll}70 & 1.00 \text { SRSX25 } & 17.60\end{array}$

$\begin{array}{lll}15 & 1.00 \text { SRSX25 } & 17.60\end{array}$

$26 \quad 1.00$ SRSX25 17.60

$50 \quad 1.00$ SASX25 $\quad 17.60$

$10 \quad 1.00$ SRSX25 17.60

$21 \quad 1.00$ SRSX25 $\quad 17.60$

$\begin{array}{lll}7 & 1.00 \text { SASX25 } & 17.60\end{array}$

$\begin{array}{lll}8 & 1.00 \text { SRSX14 } 15.60\end{array}$

$39 \quad 1.00$ SASX25 17.60

$13 \quad 1.00$ SRSX25 17.60

$70 \quad 1.00$ SASX25 $\quad 17.60$
7.00

$\begin{array}{lll}7 & 1.00 \text { SPSX25 } & 17.60\end{array}$

$\begin{array}{lll}7 & 1.00 \text { SRSX25 } & 17.60\end{array}$

$35 \quad 1.00$ SASX25 17.60

$\begin{array}{ll}2400.00 & 3.600 \\ 3100.00 & 3.600\end{array}$

$\begin{array}{lll}280 & 1.00 \text { SRSX25 } & 17.60\end{array}$

$\begin{array}{lll}6 & 1.00 \text { SRSX25 } & 17.60\end{array}$

21.00 SRSX14 15.60

$24 \quad 1.00$ SRSX26 17.10

$33 \quad 1.00$ SRSX25 17.60

$\begin{array}{lll}19 & 1.00 \text { SRSX25 } & 17.60\end{array}$

$89 \quad 1.00$ SRSX25 17.60

$41 \quad 1.00$ SRSX25 $\quad 17.60$

$\begin{array}{lll}13 & 1.00 \text { SRSX25 } & 17.60\end{array}$

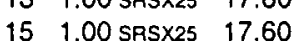

$46 \quad 1.00$ SRSX25 $\quad 17.60$

$\begin{array}{lll}10 & 1.00 \text { SRS } \times 25 & 17.60\end{array}$

$\begin{array}{lll}4,680 & 1.00 \text { SRSX25 } & 17.60\end{array}$

$176 \quad 1.00$ SRSX2s

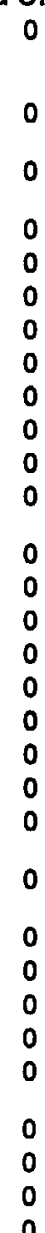

13,075

17.60

WBS 1.2.1.02

1310 INSTALL NEW COOLING WATER PUMPS $[50.000 \mathrm{GPM}$ T.SOOHFI

6
4.0EA $\quad 300000.00 \quad 420.000$

(10.0)EA
SITE \#2, COOLING OPTION \#2

$0 \quad 1.00$ SAS $\times 01$
360,000

0

0

0

0

0
0
0

0
0
0

COOLING EQUIPMENT COS

0

0

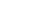

0 
FILE: APTCOOL

PROJeCT NAME: PRC._CT NAME
ENGINEERING \& CONS " MTION SERVICES DIVISION

SITE PROJLUT ESTIMATING

DETAIL LINE ITEMS
PAGE \# 2

TIME: 08:35:58

DATE 09-Aug-1996

REPORT NAME: APT Detail WBS EXCEL FORMAT

PRICING: PRE 95 OR POST 94 RATES

CRAFT CONTRACT TOTAL

WBS

TWC DESCRIPTION

QUANTTYY UOM

UNIT UNIT TTL ADJ

HOURS FACT CREW \$MH

CONST.

ENGR'D

LABOR

SERVICES

cost

GROUP : NO APT GROUP IDENTIFIED

\section{ACCOUNT CODE:}

B673 126. 10 CONCRETE PIPE

8673 126. ID PIPE JOINTS /GROUT \& GASKET-12' OD 37.7LF]

$8673126^{\circ} \times 84^{\circ}$ CONCRETE REOUCER

$39408^{\circ}$ CONCRETE PIPE, O\&R 8. THK CONCRETE [84" TIE-IN]

8673 126. FLANGE ADAPTERS

8673 126. GATE VALVE. FLG [ALLOWANCE] OINT TEST

$8673102^{\circ}$ ID CONCRETE PIPE

8673 102" ID PIPE JOINTS IGROUT \& GASKET.9.75'OD 30.6 LF]

$8673102^{*} \times 36$ CONCRETE REDUCER

8673 102" ID FLANGE ADAPTERS

$8714102 \cdot$ ID GATE VALVE, FLG [ALLOWANCE] 8912 102' ID PNEUMATIC PIPE
JOINT TEST

8317 42" CS PIPE, SCH 10

8317 42" TEE

$831742^{*} E L L, 90$

8317 42" FLANGE, WN

8714 42. GATE VALVE, FLG

8520 42. PIPE SUPPORT [ALLOWANCE]

8912 42" PIPE HYDROTEST

$831736^{\circ}$ CS PIPE, SCH 10

๑317 36" TEE

$831736^{\circ}$ ELL, 90

$831736^{\circ}$ FLANGE, WN

8714 36. GATE VALVE, FLG

$871436^{\circ}$ CHECK VALVE, FLG

$852036^{\circ}$ PIPE SUPPORT [ALLOWANCE] $1300 \mathrm{LF}$

8912 36' PIPE HYDROTEST

3211 MACHINE EXCAVATE FOR SITE

3221 FUANISH \& PLACE PIPE BEDDING SAND $8673126^{\circ}$ ID PNEUMATIC PIPE

4569 42" PIPE - PRIME \& PAINT - 120

$456936^{\circ}$ PIPE - PAIME \& PAINT

3212 HANO EXCAVATE FOR SITE

\begin{tabular}{|c|c|c|c|c|c|c|}
\hline & \multicolumn{2}{|c|}{ WBS 1.2.1.02 } & & \multicolumn{3}{|c|}{ SITE \#2, COOLING } \\
\hline $18,000.0 \mathrm{LF}$ & 575.00 & 3.500 & 63,000 & 1.00 SRSX25 & 17.60 & \\
\hline $450.0 \mathrm{EA}$ & 0.00 & 62.000 & 27,900 & 1.00 SRS $\times 25$ & 17.60 & \\
\hline $1.0 \mathrm{EA}$ & 41000.00 & 20.000 & 20 & 1.00 SRS $\times 25$ & 17.60 & \\
\hline $1.0 \mathrm{LS}$ & 1000.00 & 180.000 & 180 & 1.00 SRSX26 & 17.10 & \\
\hline $4.0 \mathrm{EA}$ & 32000.00 & 60.000 & 240 & $1.00 \mathrm{SRS} \times 25$ & 17.60 & \\
\hline $2.0 \mathrm{EA}$ & 40000.00 & 80.000 & 160 & 1.00 SRS $\times 25$ & 17.60 & \\
\hline $450.0 \mathrm{EA}$ & 0.00 & 2.400 & 1,080 & $1.00 \mathrm{SRS} \times 25$ & 17.60 & \\
\hline $24,000.0 \mathrm{LF}$ & 388.00 & 2.800 & 67,200 & $1.00 \mathrm{SRS} \times 25$ & 17.60 & \\
\hline $600.0 \mathrm{EA}$ & 0.00 & 50.000 & 30,000 & 1.00 SRS $\times 25$ & 17.60 & \\
\hline $1.0 \mathrm{EA}$ & 4500.00 & 16.000 & 16 & 1.00 SAS $\times 25$ & 17.60 & \\
\hline $4.0 \mathrm{EA}$ & 17000.00 & 48.000 & 192 & 1.00 SRSX25 & 17.60 & \\
\hline $2.0 \mathrm{EA}$ & 32000.00 & 64.000 & 128 & 1.00 SAS $\times 25$ & 17.60 & \\
\hline $600.0 \mathrm{EA}$ & 0.00 & 2.000 & 1,200 & $1.00 \mathrm{SRS} \times 25$ & 17.60 & \\
\hline $120.0 \mathrm{LF}$ & 102.00 & 1.600 & 192 & 1.00 SRS $\times 25$ & 17.60 & \\
\hline $3.0 \mathrm{EA}$ & 2200.00 & 68.000 & 204 & $1.00 \mathrm{SRS} \times 25$ & 17.60 & \\
\hline 4.0 EA & 1300.00 & 48.000 & 192 & $1.00 \mathrm{SRS} \times 25$ & 17.60 & \\
\hline 12.0 EA & 1000.00 & 26.000 & 312 & $1.00 \mathrm{SRS} \times 25$ & 17.60 & \\
\hline 4.0 EA & 37000.00 & 48.000 & 192 & 1.00 SRSX25 & 17.60 & \\
\hline $8.0 \mathrm{EA}$ & 100.00 & 30.000 & 240 & $1.00 \mathrm{SRS} \times 25$ & 17.60 & \\
\hline $1,320.0 \mathrm{SF}$ & 0.60 & 0.100 & 132 & 1.00 sRS $\times 14$ & 15.60 & \\
\hline $120.0 \mathrm{LF}$ & 0.00 & 0.600 & 72 & 1.00 SRS $\times 25$ & 17.60 & \\
\hline $140.0 \mathrm{LF}$ & 95.00 & 1.500 & 210 & 1.00 SRS $\times 25$ & 17.60 & \\
\hline 3.0 EA & 2100.00 & 59.000 & 177 & 1.00 SRS $\times 25$ & 17.60 & \\
\hline 8.0 EA & 1200.00 & 42.000 & 336 & 1.00 SAS $\times 25$ & 17.60 & \\
\hline $20.0 \mathrm{EA}$ & 940.00 & 24.000 & 480 & 1.00 SRS $\times 25$ & 17.60 & \\
\hline $4.0 \mathrm{EA}$ & 35000.00 & 34.000 & 136 & $1.00 \mathrm{SRS} \times 25$ & 17.60 & \\
\hline $4.0 \mathrm{EA}$ & 30000.00 & 34.000 & 136 & $1.00 \mathrm{SRS} \times 25$ & 17.60 & \\
\hline $6.0 \mathrm{EA}$ & 75.00 & 25.000 & 150 & $1.00 \mathrm{SRS} \times 25$ & 17.60 & \\
\hline $1,320.0 \mathrm{SF}$ & 0.60 & 0.100 & 132 & 1.00 SRS $\times 14$ & 15.60 & \\
\hline $140.0 \mathrm{LF}$ & 0.00 & 0.368 & 52 & 1.00 SRSX25 & 17.60 & \\
\hline $220,409.0 \mathrm{CY}$ & 0.00 & 0.030 & 6,612 & 1.00 SRSXOS & 16.20 & 2,7 \\
\hline $4.500 .0 \mathrm{CY}$ & 0.00 & 4.000 & 18,000 & 1.00 SRSX04 & 11.80 & \\
\hline $8,834.0 \mathrm{CY}$ & 8.00 & 0.830 & 7,332 & 1.00 SRSX04 & 11.80 & \\
\hline
\end{tabular}

ON \#2
$10,350,00$

$10,350,000$

41,000

0

128,000

80,000

0

$9,312,000$

4,500

68,000

64,000

0

12,240

6,600

5,200

12,000

148,000

0

0

0

13,300

6,300

9,600

18,800

40,000

120,000

0

0

0

0
0

MATL

$====$

$=====$

\begin{tabular}{|c|c|c|c|}
\hline $\begin{array}{l}0 \\
0\end{array}$ & $\begin{array}{r}1,108,800 \\
491,040\end{array}$ & $\begin{array}{l}0 \\
0\end{array}$ & $\begin{array}{r}11,458,800 \\
491,040\end{array}$ \\
\hline 0 & 352 & 0 & 41,352 \\
\hline 1,000 & 3,078 & 0 & 4,078 \\
\hline $\begin{array}{l}0 \\
0\end{array}$ & $\begin{array}{l}4,224 \\
2,816\end{array}$ & $\begin{array}{l}0 \\
0\end{array}$ & $\begin{array}{r}132,224 \\
82,816\end{array}$ \\
\hline 0 & 19,008 & 0 & 19,008 \\
\hline $\begin{array}{l}0 \\
0\end{array}$ & $\begin{array}{r}1,182,720 \\
528,000\end{array}$ & $\begin{array}{l}0 \\
0\end{array}$ & $\begin{array}{r}10,494,720 \\
528,000\end{array}$ \\
\hline 0 & 282 & 0 & 4,782 \\
\hline $\begin{array}{l}0 \\
0\end{array}$ & $\begin{array}{l}3,379 \\
2,253\end{array}$ & $\begin{array}{l}0 \\
0\end{array}$ & $\begin{array}{l}71,379 \\
66,253\end{array}$ \\
\hline 0 & 21,120 & 0 & 21,120 \\
\hline 0 & 3,379 & 0 & 15,619 \\
\hline 0 & 3,590 & 0 & 10,190 \\
\hline 0 & 3,379 & 0 & 8,579 \\
\hline 0 & 5,491 & 0 & 17,491 \\
\hline non & $3,3 / 9$ & 0 & 151,379 \\
\hline & & & 5,024 \\
\hline 792 & 2,059 & 0 & 2,851 \\
\hline 0 & 1,267 & 0 & 1,267 \\
\hline 0 & 3,696 & 0 & 16,996 \\
\hline 0 & 3,115 & 0 & 9,415 \\
\hline 0 & 5,914 & 0 & 15,514 \\
\hline 0 & 8,448 & 0 & 27,248 \\
\hline 0 & 2,394 & 0 & 142,394 \\
\hline 0 & 2,394 & 0 & 122,394 \\
\hline 450 & 2,640 & 0 & 3,090 \\
\hline 792 & 2,059 & 0 & 2,851 \\
\hline 0 & 907 & 0 & 907 \\
\hline 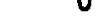 & 107,119 & 0 & 309,895 \\
\hline $\begin{array}{r}0 \\
672\end{array}$ & 212,400 & 0 & 212,400 \\
\hline 672 & 86,520 & 0 & 157,192 \\
\hline
\end{tabular}


FILE: APTCOOL:

PROJECT NAME: PROu_CT NAME
ENGINEERING \& CONS ${ }^{-\cdots}$ 'LION SERVICES DIVISION

SITE PROJLUT ESTIMATING

DETAIL LINE ITEMS
PAGE * 3

TIME: 08:35:58

DATE O9-Aug-1996

REPORT NAME: APT Detail WBS EXCEL FORMAT

PRICING: PRE 95 OR POST 94 RATES

CRAFT CONTRACT TOTAL

WBS TWC DESCRIPTION OUANTTY UOM UNIT

UNIT

TTL ADJ

FACT CREW \$/MH

ENGRD

ACCOUNT CODE

$\begin{array}{ll}3221 & \text { TRENCH BACKFILL \& } \\ \text { COMPACTION } \\ 3216 \text { HAUL \& OUMP (EXCESS) } \\ 4160 \text { CONCRETE FOR PUMP PADS } \\ 4140 \text { REBAR FOR FOR PUMP PADS } \\ 4120 \text { FORMWORK FOR PUMP } \\ \text { PADS } \\ 4140 \text { FURNISH FAB \& PLACE } \\ \text { COVER GRATING }\end{array}$

$107.627 .0 \mathrm{CY}$

WBS 1.2.1.02

$117,294.0 \mathrm{cY}$

$20.0 \mathrm{CY}$

1.0 TON

$0.00 \quad 0.060$

$\begin{array}{lll}6,458 & 1.00 \text { SRSX05 } \quad 16.20\end{array}$

88,254

$\begin{array}{rr}0.00 & 1.200 \\ 60.00 & 2.500 \\ 600.00 & 20.000\end{array}$

$140,753 \quad 1.00$ SRSXOS $\quad 16.20$

$\begin{array}{lll}50 & 1.00 \text { SRS } \times 10 \quad 12.20\end{array}$

$20 \quad 1.00$ SRSX08 17.30

0
0
0
0

$\begin{array}{lll}800.0 \mathrm{SF} & 8.35 & 0.093\end{array}$

$82 \quad 1.00$ SRSX07 $\quad 14.60$

$\begin{array}{lll}74 & 1.00 \text { SRSX12 } & 17.50\end{array}$

1,296

LABOR SERVICES

COST

FURNISH FAB \& PLACE
COVER/ GRATING

WBS1.2.1.02 SITE \#2, COOLING OPTION \#2 SUBTOTAL

3720 6. DIA WELL CASING WI PUMP (500 GPM 15 HP)

WELL FIELD TANK [23.5' DIAX

15.5' HIGH - 50000 GAL

6" PIPE, STN STL

G. FLANGE, WN

6. GATE VALVe, FLG

6. CHECK VAlVE FLG

6. CONTROL VALVE, FLG

G. PIPE SUPPORT, STN STL

6" HYOROTEST

6. PIPE, PVC

6. AYDROTEST

$10^{\circ}$ PIPE. PVC

10. HYOROTEST

18. PIPE, PVC

$18^{\circ}$ HYDROTEST

$14^{\circ}$ PIPE, CS

$14^{\circ}$ TEE

$14^{\circ} \mathrm{ELL}, 90$

14. Gate Valve, flg

14. CHeck VAlve, FLG

14. FLANGE, WN

14. PIPE SUPPORT, CS

$18^{\circ} \times 14^{\circ}$ REDUCER

$14^{\circ}$ HYOROTEST

14. PIPE - PRIME \& PAINT - 10

LF

16" PIPE, CS

16. TEE

$16^{\circ}$ ELL, 90

16. GATE VALVE, FLG

\begin{tabular}{rrr} 
& \multicolumn{2}{c}{ WBS 1.2 .1 .03} \\
$18.0 \mathrm{EA}$ & 0.00 & 0.000 \\
$1.0 \mathrm{EA}$ & 0.00 & 0.000 \\
& & \\
$180.0 \mathrm{LF}$ & 32.00 & 0.390 \\
$36.0 \mathrm{EA}$ & 95.00 & 9.400 \\
$144.0 \mathrm{EA}$ & 167.00 & 9.200 \\
$36.0 \mathrm{EA}$ & 3000.00 & 3.100 \\
$18.0 \mathrm{EA}$ & 2100.00 & 3.100 \\
$18.0 \mathrm{EA}$ & 19000.00 & 6.000 \\
$36.0 \mathrm{EA}$ & 75.00 & 16.000 \\
$180.0 \mathrm{LF}$ & 0.00 & 0.250 \\
$1,800.0 \mathrm{LF}$ & 1.60 & 0.140 \\
$1,800.0 \mathrm{LF}$ & 0.00 & 0.150 \\
$24,000.0 \mathrm{LF}$ & 12.20 & 0.150 \\
$24,000.0 \mathrm{LF}$ & 0.00 & 0.310 \\
$6,000.0 \mathrm{LF}$ & 13.50 & 0.250 \\
$6,000.0 \mathrm{LF}$ & 0.00 & 0.250 \\
$10.0 \mathrm{LF}$ & 25.80 & 0.830 \\
$1.0 \mathrm{EA}$ & 430.00 & 23.000 \\
$2.0 \mathrm{EA}$ & 280.00 & 15.000 \\
$2.0 \mathrm{EA}$ & 7500.00 & 5.100 \\
$2.0 \mathrm{EA}$ & 4800.00 & 5.100 \\
$10.0 \mathrm{EA}$ & 220.00 & 6.200 \\
$4.0 \mathrm{EA}$ & 40.00 & 12.000 \\
$1.0 \mathrm{EA}$ & 260.00 & 17.000 \\
$10.0 \mathrm{LF}$ & 0.00 & 0.380 \\
$40.0 \mathrm{SF}$ & 0.70 & 0.108 \\
& & \\
$10.0 \mathrm{LF}$ & 30.80 & 0.890 \\
$1.0 \mathrm{EA}$ & 520.00 & 26.000 \\
$2.0 \mathrm{EA}$ & 380.00 & 18.000 \\
$2.0 \mathrm{EA}$ & 10200.00 & 5.900 \\
& &
\end{tabular}

375,722

$0 \quad 1.00$

16.63

292,326

01.00

SITE \#2, COOLING OPTION \#3

$\begin{array}{lll}70 & 1.00 \text { SRSX25 } & 17.60\end{array}$

$\begin{array}{lll}338 & 1.00 \text { SRSX25 } & 17.60\end{array}$

$\begin{array}{lll}1,325 & 1.00 \text { SRSX25 } \quad 17.60\end{array}$

$\begin{array}{lll}112 & 1.00 \text { SRSX25 } & 17.60\end{array}$

$\begin{array}{ll}56 & 1.00 \text { SRS } \times 25 \quad 17.60\end{array}$

$108 \quad 1.00$ SRS $\times 25 \quad 17.60$

$\begin{array}{lll}576 & 1.00 \text { SASX25 } & 17.60\end{array}$

$\begin{array}{lll}45 & 1.00 \text { SRSX25 } \quad 17.60\end{array}$

2521.00 SRSX25 $\quad 17.60$

$270 \quad 1.00$ SASX25 $\quad 17.60$
0.600

$3.600 \quad 1.00$ SASX25 $\quad 17.60$

$7,440 \quad 1.00$ SRSX25 $\quad 17.60$

$\begin{array}{ll}1,500 \quad 1.00 \text { SRSX25 } \quad 17.60 \\ 1,500 \quad 1.00 \text { SRSX25 } & 17.60\end{array}$

$\begin{array}{lll}1,500 & 1.00 \text { SRS } \times 25 \quad 17.60\end{array}$

$8 \quad 1.00$ SRSX25 17.60

$23 \quad 1.00$ SRSX25 17.60

$30 \quad 1.00$ SRSX25 17.60

$\begin{array}{lll}10 & 1.00 \text { SRSX25 } & 17.60\end{array}$

$\begin{array}{lll}10 & 1.00 \text { SRSX25 } & 17.60\end{array}$

$62 \quad 1.00$ SASX25 17.60

$\begin{array}{lll}48 & 1.00 \text { SRSX25 } \quad 17.60\end{array}$

$17 \quad 1.00$ SRSX25 $\quad 17.60$

41.00 SRS $\times 25 \quad 17.60$

41.00 SRSX $14_{14} \quad 15.60$

$\begin{array}{lll}9 & 1.00 \text { SRS } \times 25 & 17.60\end{array}$

$\begin{array}{ll}26 & 1.00 \text { SRS } \times 25 \quad 17.60\end{array}$

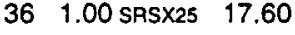

121.00 SRSX25 17.60

$\begin{array}{lr}0 & 0 \\ 0 & 0 \\ 0 & 0 \\ 0 & 0 \\ 0 & 0 \\ 0 & 108,000 \\ 0 & 37,800 \\ 0 & 342,000 \\ 0 & 0 \\ 0 & 0 \\ 0 & 0 \\ 0 & 0 \\ 0 & 0 \\ 0 & 0 \\ 0 & 0 \\ 0 & 0 \\ 0 & 0 \\ 0 & 0 \\ 0 & 0 \\ 0 & 15,000 \\ 0 & 9,600 \\ 0 & 0 \\ 0 & 0 \\ 0 & 0 \\ 0 & 0 \\ 0 & 0 \\ 0 & 0 \\ 0 & 0 \\ 0 & 0 \\ 0 & 20,400\end{array}$

0
0
0
0
0
0

\begin{tabular}{rrrr}
0 & 104,613 & 0 & 192,868 \\
0 & $2,280,195$ & 0 & $2,280,195$ \\
1,200 & 610 & 0 & 1,810 \\
600 & 346 & 0 & 946 \\
123 & 1,197 & 0 & 1,320 \\
6,680 & 1,302 & 0 & 9,278 \\
\hline 83,109 & $6,249,278$ & 0 & $22,744,254$
\end{tabular}

192,868

0,195

946

1,320

9,278 
FILE: APTCOOL:

PRoJect NAME: PRO $=$ CT NAME
ENGINEERING \& CONS* I IION SERVICES DIVISION

SITE PROJLUT ESTIMATING

DETAIL LINE ITEMS
PAGE * 4

TIME: $\quad 08: 35: 58$

DATE 09-Aug-1996

PRICING: PRE 95 OR POST 94 RATES

REPORT NAME: APT Detall WBS EXCEL FORMAT

\begin{tabular}{|c|c|c|c|c|c|c|c|c|c|c|c|c|c|c|}
\hline WBS & TWC & DESCRIPTION & QUANTITY & UOM & $\begin{array}{l}\text { UNIT } \\
\text { MATL }\end{array}$ & $\begin{array}{l}\text { UNIT } \\
\text { MHRS }\end{array}$ & $\begin{array}{l}\text { TTL } \\
\text { HOURS }\end{array}$ & $\begin{array}{l}\text { ADJ } \\
\text { FACT CREW }\end{array}$ & $\$ / M H$ & $\begin{array}{l}\text { CONST. } \\
\text { EQUIP. }\end{array}$ & $\begin{array}{l}\text { ENGR'D } \\
\text { EQUIP. }\end{array}$ & MAT'L & $\begin{array}{l}\text { CRAFT } \\
\text { LABOR }\end{array}$ & $\begin{array}{r}\text { CONTRACT } \\
\text { SERVICES }\end{array}$ \\
\hline
\end{tabular}

GROUP: NO APT GROUP IDENTIFIED ACCOUNT CODE:

16. PIPE SUPPORT, CS

$16^{\circ}$ HYDROTEST

16. PIPE - PRIME \& PAINT - 10 LF

3211 MACHINE EXCAVATE FOR

3212 HANO EXCAVATE FOR SITE

3221 FURNISH \& PLACE PIPE

3221 TRENCH BACKFILL

3216 HAUL \& DUMP (EXCESS)

$831518^{\circ}$ PIPE, CS. STD

8315 18. FLANGE, WN, 150"

$831518^{\circ}$ ELL. 90

8714 18. GATE VALVE, FLG, CS

8714 18. FLOW CONTROL VALVE, FLG, CS

$831318^{*}$ BOLT.UP W/B\&G SET

\begin{tabular}{rrr} 
& \multicolumn{2}{c}{ WBS 1.2 .1 .03} \\
$6.0 \mathrm{EA}$ & 350.00 & 6.900 \\
$4.0 \mathrm{EA}$ & 50.00 & 15.000 \\
$10.0 \mathrm{LF}$ & 0.00 & 0.440 \\
$40.0 \mathrm{SF}$ & 0.60 & 0.100 \\
& & \\
$12,024.0 \mathrm{CY}$ & 0.00 & 0.030 \\
& & \\
$4,008.0 \mathrm{CY}$ & 0.00 & 4.000 \\
$1,629.0 \mathrm{CY}$ & 8.00 & 0.830 \\
$13,139.0 \mathrm{CY}$ & 0.00 & 0.060 \\
$3,360.0 \mathrm{Cr}$ & 0.00 & 1.200 \\
$20.0 \mathrm{LF}$ & 51.50 & 0.950 \\
$7.0 \mathrm{EA}$ & 480.00 & 12.700 \\
$2.0 \mathrm{EA}$ & 490.00 & 20.500 \\
$2.0 \mathrm{EA}$ & 12400.00 & 6.700 \\
$1.0 \mathrm{EA}$ & 30000.00 & 15.000 \\
$7.0 \mathrm{EA}$ & 68.00 & 6.600
\end{tabular}

SITE \#2, COOLING OPTION \#3

$41 \quad 1.00$ SRSX25 17.60

$\begin{array}{lll}41 & 1.00 \text { SRS } \times 25 & 17.60 \\ 60 & 1.00 \text { SRSX25 } & 17.60\end{array}$

41.00 SRSX25 17.60

$\begin{array}{lll}4 & 1.00 \text { SRSX } 14 & 15.60\end{array}$

3611.00 SRS $\times 05 \quad 16.20$

$\begin{array}{ll}16.032 \quad 1.00 \text { SRS } \times 04 \quad 11.80 \\ 1.352 & 1.00 \text { SRS }\end{array}$

$1,352 \quad 1.00$ SRSX04 11.80

0
0
0
0

129

0

11,062

$\begin{array}{lll}788 & 1.00 \text { SASX05 } \quad 16.20\end{array}$

0

$\begin{array}{lll}4,032 & 1.00 \text { SASX05 } \quad 16.20\end{array}$

$\begin{array}{lll}19 & 1.00 \text { SRS } \times 25 & 17.60\end{array}$

$89 \quad 1.00$ SRSX25 17.60

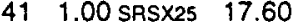

$13 \quad 1.00$ SRS $\times 25 \quad 17.60$

$\begin{array}{lll}15 & 1.00 \text { SRSX25 } & 17.60\end{array}$

10,774

$46 \quad 1.00$ SRSX25 $\quad 17.60$

WBS1.2.1.03 SITE \#2, COOLING OPTION \#3 SUBTOTAL

WBS 1.2.1.04

3211 MACHINE EXCAVATE FOR SITE

3212 MAND EXCAVATE FOR SITE

3221 FURNISH \& PLACE PIPE BEDDING SAND

3221 TRENCH BACKFILL COMPACTION

3216 HAUL \& DUMP (EXCESS)

4160 CONCRETE PUMP PADS

4140 REBAR FOR PUMP PADS

4120 FORMWORK FOR PUMP PADS

4140 FURNISH FAB \& PLACE COVER GRATING

1310 COOLING WATER PUMPS [50000GPM $\odot 2250 \mathrm{HP}$ ]

1400 ADJUSTMENT FOR COOUNG EQUIPMENT (DELETE CT)

8673 84. ID CONCRETE PIPE

8673 84. ID PIPE JOINT [GROUT \& GASKET-8.25' OD 025.9 LF]

$394084^{\circ}$ CONCRETE PIPE, DQR 8. THK CONCAETE [84. TIE-IN]

$867384^{\circ}$ ID FLANGE ADAPTERS

$58,300.0 \mathrm{LF}$

1,458.0 EA

$2.0 \mathrm{EA}$

$0.00 \quad 42.000$

$1180.00 \quad 180.000$

$8000.00 \quad 54.000$

\begin{tabular}{rrr} 
& \multicolumn{2}{c}{ WBS 1.2 .1 .04} \\
$225.957 .0 \mathrm{CY}$ & 0.00 & 0.030 \\
$4,600.0 \mathrm{CY}$ & 0.00 & 4.000 \\
$10.380 .0 \mathrm{CY}$ & 8.00 & 0.830 \\
$123,626.0 \mathrm{CY}$ & 0.00 & 0.060 \\
$122,981.0 \mathrm{cr}$ & 0.00 & 1.200 \\
$20.0 \mathrm{cr}$ & 60.00 & 2.500 \\
$1.0 \mathrm{TON}$ & 600.00 & 20.000 \\
$164.0 \mathrm{SFCA}$ & 0.75 & 0.500 \\
$800.0 \mathrm{SF}$ & 8.35 & 0.093 \\
$4.0 \mathrm{EA}$ & 400000.00 & 720.000 \\
& &
\end{tabular}

14.92

SITE \#2, COOLING OPTION \#4

1.00 SASX05 $\quad 16.20 \quad 207,880$ $\begin{array}{lll}18,400 \quad 1.00 \text { SASX04 } & 11.80\end{array}$

$8,615 \quad 1.00$ SRSX04 11.80

$\begin{array}{lll}7,418 & 1.00 \text { SRSX05 } \quad 16.20\end{array}$

$\begin{array}{lll}147.577 & 1.00 \text { SASXOS } \quad 16.20\end{array}$

$\begin{array}{lll}50 & 1.00 \mathrm{SAS} \times 10 & 12.20\end{array}$

$20 \quad 1.00$ SRSX0B $\quad 17.30$

821.00 SAS $\times 07 \quad 14.60$

$\begin{array}{lll}74 & 1.00 \text { SRSX12 } 17.50\end{array}$

$2,880 \quad 1.00$ SRSX01 $\quad 17.60$

01.00

$245.00 \quad 1.400$

$81,620 \quad 1.00$ SRS $\times 25 \quad 17.60$

$61,236 \quad 1.00$ SRS $\times 25 \quad 17.60$

$\begin{array}{lll}360 & 1.00 \mathrm{SRS} \times 26 \quad 17.10\end{array}$

4321.00 SRSX25 $\quad 17.60$

0
0

101,373

0

0
0
0

1,296

o $1,600,000$

$$
0
$$

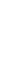

0
0

$14,283,500$

0

0

0

8.0 EA $\quad 8000.00 \quad 54.000$

0
0
0
0
0
0
0
0
0
0
0
0
0
0


FILE: APTCOOL

PRoject NAME: PROucCT NAME
ENGINEERING \& CONS - $^{-1}$ ICTION SERVICES DIVISION

SITE PROJEUT ESTIMATING

DETAIL LINE ITEMS
PAGE 5

TIME: 08:35:58

DATE 09-AUg-1996

REPORT NAME: APT Detall WBS EXCEL FORMAT

PRICING: PRE 95 OR POST 94 RATES

"

UNIT UNIT TTL ADJ CONST.

MATL

LABOR

SERVICES

COST

GROUP : NO APT GROUP IDENTIFIED ACCOUNT CODE:

\section{84" ID GATE VALVE. FLG} [ALLOWANCE]

$394084^{\circ}$ CONCRETE PIPE $D \& A$

$967384^{\circ}$ CONCRETE PIPE CAP

8912 84. 10 PNEUMATIC PIPE JOINT

$867378^{\circ} 10$ CONCRETE PIPE

$867378^{\circ}$ ID PIPE JOINT [GROUT \& GASKET. $75^{\prime} \cdot 23.6$ LFI

$867378^{\circ} 10$ CONCRETE TIE.IN

$691278^{\circ}$ ID PNUEMATIC PIPE JOINT TEST

8317 42" CS PIPE, SCH 10

$831742^{\circ}$ TEE

8317 42. ELL, 90

8317 42. FLANGE, WN

871442 . Gate ValVe, FLG

5520 42. PIPE SUPPORT

[ALLOWANCE]

$456942^{\circ}$ PIPE - PRIME \& PAINT - 120 LF

8912 42. PIPE HYDROTEST

B317 $36^{\circ} \mathrm{CS}$ PIPE, SCH 10

$831736^{\circ}$ TEE

$831736^{\circ} \mathrm{ELL}, 90$

8317 36. FLANGE, WN

8714 36" GATE VALVE, FLG

$871436^{\circ}$ CHECK VALVE, FLG

$852036^{\circ}$ PIPE SUPPORT

[ALLOWANCE]

$456936^{\circ}$ PIPE - PRIME \& PAINT .

$$
1300 \text { LF }
$$

\section{$===$}

MATL MHRS HOURS FACT CREW \$/MH

\section{\#2, COOLING OPTION \#4}

4.0 EA

WBS 1.2.1.04

$\begin{array}{lll}48.0 \mathrm{LF} & 0.00 \quad 2.600\end{array}$

$\begin{array}{lll}8.0 \mathrm{EA} & 8800.00 \quad 42.000\end{array}$

$\begin{array}{lrr}1,458.0 \mathrm{EA} & 0.00 \quad 1.800\end{array}$

600.0 LF $\quad 233.00 \quad 1.400$

$15.0 \mathrm{EA}$

4.0 EA

15.0 EA

$120.0 \mathrm{LF}$

3.0 EA

4.0 EA

$12.0 \mathrm{EA}$

4.0 EA

8.0 EA

$1,320.0 \mathrm{SF}$

$120.0 \mathrm{LF}$

$140.0 \mathrm{LF}$

$140.0 \mathrm{LF}$
$3.0 \mathrm{EA}$

$8.0 \mathrm{EA}$

$20.0 \mathrm{EA}$

4.0 EA

$4.0 \mathrm{EA}$

$6.0 \mathrm{EA}$

$1,320.0 \mathrm{SF}$

$140.0 \mathrm{LF}$
$224 \quad 1.00$ SRSX25 $\quad 17.60$

$\begin{array}{lll}125 & 1.00 \text { SASX25 } \quad 17.60\end{array}$

$336 \quad 1.00$ SASX25 17.60

$\begin{array}{lll}2,624 & 1.00 \text { SRSX25 } \quad 17.60\end{array}$

$840 \quad 1.00$ SASX25 $\quad 17.60$

$\begin{array}{lll}585 & 1.00 \text { SRSX25 } \quad 17.60\end{array}$

$\begin{array}{ll}680 & 1.00 \text { SRSX25 } \quad 17.60\end{array}$

$24 \quad 1.00$ SRSX25 17.60

$\begin{array}{rr}950.00 & 170.000 \\ 1.60 & 1.600\end{array}$

$102.00 \quad 1.600$

$2200.00 \quad 68.000$

$1300.00 \quad 48.000$

$1000.00 \quad 26.000$

$37000.00 \quad 48.000$

$100.00 \quad 30.000$

$0.60 \quad 0.100$

$0.00 \quad 0.600$

$95.00 \quad 1.500$

$2100.00 \quad 59.000$

$1200.00 \quad 42.000$

$940.00 \quad 24.000$

$35000.00 \quad 34.000$

$30000.00 \quad 34.000$

$75.00 \quad 25.000$

$0.60 \quad 0.100$

$0.00 \quad 0.368$

$\begin{array}{lll}72 & 1.00 \text { SRSX25 } & 17.60\end{array}$ $\begin{array}{lll}192 & 1.00 \text { SASX25 } \quad 17.60\end{array}$

2041.00 SRSX25 17.60

$\begin{array}{lll}192 & 1.00 \text { SRSX25 } \quad 17.60\end{array}$

$\begin{array}{lll}312 & 1.00 \text { SASX25 } & 17.60\end{array}$

$\begin{array}{lll}192 & 1.00 \text { SPSX25 } & 17.60\end{array}$

$\begin{array}{ll}240 & 1.00 \text { SRSX25 } \\ 17.60\end{array}$

$132 \quad 1.00$ SASX14 15.60

$\begin{array}{lll}210 & 1.00 \text { SASX25 } & 17.60\end{array}$

$\begin{array}{lll}177 & 1.00 \text { SRS } \times 25 \quad 17.60\end{array}$

$\begin{array}{lll}336 & 1.00 \text { SASX25 } & 17.60\end{array}$

$\begin{array}{lll}480 & 1.00 \text { SRSX } 25 & 17.60\end{array}$

$\begin{array}{lll}136 & 1.00 \text { SRSX25 } 17.60\end{array}$

$136 \quad 1.00$ SRSX25 17.60

$\begin{array}{lll}150 & 1.00 \text { SRS } \times 25 \quad 17.60\end{array}$

$132 \quad 1.00$ SRSX $14 \quad 15.60$

$52 \quad 1.00$ SRSX25 $\quad 17.60$

\section{2,000}

0
70,400

0

139,800

3,800

24

12,240

6,600

5,200

12,000

148,000

0

0

0
13,300

13,300

6,300

9,600

18,800

140,000

120,000

0

0

WBS1.2.1.04 SITE \#2, COOLING OPTION \#4 SUBTOTAL

344,326

16.48

16.48

310,550

SITE \#8, COOLING OPTION \#1

1940 REMOVE EXISTING RWS PUMPS (25000 GPM 3000

1310 INSTALL NEW RWS PUMPS [6000 GPM $850 \mathrm{HP}$ ]

4270 MODIFY INLET CONN. - 46. $x$ $36^{\circ} \times 1 / 4^{\prime}$ STEEL PLATE [75")]

$831736^{\circ} \times 12^{\circ}$ CS REDUCER

$831312^{\circ}$ PIPE, CS. STD

8313 12. ELL. 90

B313 12* FLANGE, WN, 150*

\begin{tabular}{rrr} 
& \multicolumn{2}{c}{ WBS 1.2 .1 .05} \\
$2.0 \mathrm{EA}$ & 0.00 & 940.000 \\
& & \\
$2.0 \mathrm{EA}$ & 180000.00 & 250.000 \\
& & \\
$2.0 \mathrm{EA}$ & 45.00 & 11.250 \\
& & \\
$2.0 \mathrm{EA}$ & 720.00 & 35.000 \\
$20.0 \mathrm{LF}$ & 29.20 & 0.770 \\
$2.0 \mathrm{EA}$ & 205.00 & 13.000 \\
$6.0 \mathrm{EA}$ & 150.00 & 8.300
\end{tabular}

$1,880 \quad 1.00$ SRSXO1 17.60

$500 \quad 1.00$ SRSXO1 17.60

231.00 SRSXO 17.60

$\begin{array}{lll}70 & 1.00 \text { SASX25 } & 17.60\end{array}$

$\begin{array}{lll}15 & 1.00 \text { SASX25 } & 17.60\end{array}$

$26 \quad 1.00$ SASX25 17.60

$\begin{array}{lll}50 & 1.00 \text { SASX25 } & 17.60\end{array}$

$\begin{array}{lr}0 & 0 \\ 0 & 360,000 \\ 0 & 0 \\ 0 & 0 \\ 0 & 0 \\ 0 & 0 \\ 0 & 0\end{array}$

0
0
0

\begin{tabular}{|c|c|c|}
\hline 3,942 & 0 & 115,942 \\
\hline 2,196 & 0 & 2,196 \\
\hline 5,914 & 0 & 76,314 \\
\hline 46,189 & 0 & 46,189 \\
\hline 14,784 & 0 & 154,584 \\
\hline 10,296 & 0 & 10,296 \\
\hline 11,968 & 0 & 15,768 \\
\hline 422 & 0 & 446 \\
\hline 3,379 & 0 & 15,619 \\
\hline 3,590 & 0 & 10,190 \\
\hline 3,379 & 0 & 8,579 \\
\hline 5,491 & 0 & 17,491 \\
\hline 3,379 & 0 & 151,379 \\
\hline 4,224 & 0 & 5,024 \\
\hline 2,059 & 0 & 2,851 \\
\hline 1,267 & 0 & 1,267 \\
\hline 3,696 & 0 & 16,996 \\
\hline 3,115 & 0 & 9,415 \\
\hline 5,914 & 0 & 15,514 \\
\hline 8,448 & 0 & 27,248 \\
\hline 2,394 & 0 & 142,394 \\
\hline 2,394 & 0 & 122,394 \\
\hline 2,640 & 0 & 3,090 \\
\hline 2,059 & 0 & 2,851 \\
\hline 907 & 0 & 907 \\
\hline
\end{tabular}

$\begin{array}{rr}0 & 33,088 \\ 0 & 8,800 \\ 90 & 396 \\ 1,440 & 1,232 \\ 584 & 271 \\ 410 & 458 \\ 900 & 876\end{array}$

33,088

368,800

486

2,672

855

868
1,776 
FILE: APTCOOL

PROJECT NAME: PRUuGCT NAME
ENGINEERING \& CONS' ICTION SERVICES DIVISION

SITE PROJCUT ESTIMATING
PAGE * 6

TIME: 08:35:58

DATE 09-Aug-1996

PRICING PRE 95 OR POST 94 RATES

REPORT NAME: APT Detall WBS EXCEL FORMAT

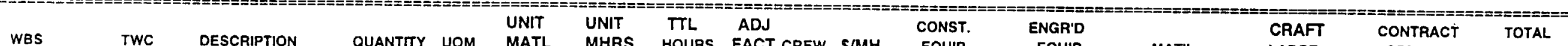

WBS TWC DESCRIPTION QUANTITY UOM

MATL MHRS HOURS FACT CREW S/MH EQUIP.

NO APT GROUP IDENTIFIED

\section{ACCOUNT CODE:}

8714 12* Gate Valve, FLG, CS

8313 12* BOLT.UP W/ B\&G SET

$89121^{\circ}$ HYOROTEST

4569 12. PIPE - PRIME \& PAINT 2OLF $831310^{\circ}$ WELDOLET, CS [66' PIPE
TIE.IN] - ALLOWANCE

$831310^{\circ}$ PIPE, CS, STD

8313 10. FLANGE, WN, 150*

$871410^{\circ}$ CHECK VALVE, FLG, CS

8714 10. GATE VALVE, FLG, CS

$831310^{\circ}$ BOLT.UP W/ BAG SET

$865310^{\circ}$ PIPE, PVC

$891210^{\circ}$ HYDROTEST

$456910^{\circ}$ PIPE - PRIME \& PAINT 2OLF

$394084^{\circ}$ CONCAETE PIPE, D\&R $8^{\circ}$ THK CONCAETE [20. TIE.IN]

$831520^{\circ}$ WELDOLET. CS (84. PIPE

$831520^{\circ}$ PIPE, CS, STO

$831520^{\circ}$ FLANGE, WN, 150"

$831520^{\circ}$ ELL. 90

8714 20. GATE VALVE, FLG, CS

$871420^{\circ}$ FLOW CONTROL VALVE,

$31320^{\circ}$ BOLT.UP W/B\&G SET

$891220^{\circ}$ HYDROTEST

$865420^{\circ}$ PIPE, PVC, BIG BLUE

$824020^{\circ} \mathrm{ELL}, 90, \mathrm{M}$,

\begin{tabular}{rrr} 
& \multicolumn{2}{c}{ WBS 1.2 .1 .05} \\
$2.0 \mathrm{EA}$ & 4000.00 & 4.800 \\
$6.0 \mathrm{EA}$ & 32.00 & 3.500 \\
$20.0 \mathrm{LF}$ & 0.00 & 0.340 \\
$70.0 \mathrm{SF}$ & 0.70 & 0.108 \\
$2.0 \mathrm{EA}$ & 100.00 & 19.400 \\
$20.0 \mathrm{LF}$ & 24.00 & 0.660 \\
$10.0 \mathrm{EA}$ & 100.00 & 7.000 \\
$2.0 \mathrm{EA}$ & 2400.00 & 3.600 \\
$2.0 \mathrm{EA}$ & 3100.00 & 3.600 \\
$10.0 \mathrm{EA}$ & 30.00 & 3.500 \\
$24,000.0 \mathrm{LF}$ & 12.20 & 0.220 \\
$20.0 \mathrm{LF}$ & 0.00 & 0.310 \\
$15.0 \mathrm{SF}$ & 0.70 & 0.108 \\
$1.0 \mathrm{LS}$ & 125.00 & 26.000 \\
& & \\
$1.0 \mathrm{EA}$ & 150.00 & 35.000 \\
& & \\
$20.0 \mathrm{LF}$ & 57.30 & 0.990 \\
$7.0 \mathrm{EA}$ & 610.00 & 14.900 \\
$2.0 \mathrm{EA}$ & 715.00 & 22.700 \\
$2.0 \mathrm{EA}$ & 15400.00 & 7.700 \\
$1.0 \mathrm{EA}$ & 32000.00 & 17.300 \\
$7.0 \mathrm{EA}$ & 100.00 & 7.500 \\
$20.0 \mathrm{LF}$ & 0.00 & 0.570 \\
$36,000.0 \mathrm{LF}$ & 20.00 & 0.280 \\
$18.0 \mathrm{EA}$ & 700.00 & 11.000
\end{tabular}

WBS1.2.1.05 SITE \#8, COOLING OPTION \#1 SUBTOTAL

1310 INSTALL NEW COOLING WATER PUMPS $[50,000 \mathrm{GPM}$

1400 COOLING EQUIPMENT COST ADJUSTMENT ( DELETE CT)

$8673102^{\circ}$ ID CONCRETE PIPE

$8673102^{\circ}$ ID PIPE JOINTS /GROUT \& GASKET-9.75' OD $\bullet 30.6 L \mathrm{~L}$

$8673102^{\prime} \times 84^{\circ}$ CONCRETE REDUCER

$394084^{\circ}$ CONCRETE PIPE, D\&R $8^{*}$ THK CONCRETE (B4. TE-IN]

$8673102^{\circ}$ FLANGE ADAPTEAS

8673 102* GATE VALVE, FLG [ALLOWANCE]

\begin{abstract}
WBS 1.2.1.06
4.0 EA $\quad 300000.00 \quad 420.000$
\end{abstract}

(10.0)EA

$86,000.0 \mathrm{LF}$

$2,150.0 \mathrm{EA}$

$1.0 \mathrm{EA}$

$1.0 \mathrm{LS}$

$8.0 \mathrm{EA}$

$4.0 \mathrm{EA}$

$\begin{array}{ll}388.00 & 2.800\end{array}$

$0.00 \quad 50.000$
$1000.00 \quad 180.000$

$17000.00 \quad 48.000$

LABOR SERVICES

COST

$=====$

LABOR

SITE \#8, COOLING OPTION \#1

$\begin{array}{lll}10 & 1.00 \text { SRSX25 } \quad 17.60\end{array}$

$21 \quad 1.00$ SAS $\times 25 \quad 17.60$

71.00 SRS $\times 25 \quad 17.60$

81.00 SRSX14 15.60

$39 \quad 1.00$ SRS $\times 25 \quad 17.60$

$\begin{array}{lll}13 & 1.00 \text { SRSX25 } \quad 17.60\end{array}$

$\begin{array}{lll}70 & 1.00 \text { SRS } \times 25 \quad 17.60\end{array}$

$\begin{array}{lll}7 & 1.00 \text { SRSX25 } & 17.60\end{array}$

$\begin{array}{lll}7 & 1.00 \text { SRSX25 } & 17.60\end{array}$

$35 \quad 1.00$ SAS $\times 25 \quad 17.60$

$\begin{array}{lll}5,280 & 1.00 \text { SRSX25 } & 17.60\end{array}$

$\begin{array}{ll}6 & 1.00 \text { SRSX25 } 17.60\end{array}$

21.00 SRS $\times 14 \quad 15.60$

$\begin{array}{lll}26 & 1.00 \text { SASX26 } & 17.10\end{array}$

$35 \quad 1.00 \operatorname{sRS} \times 25 \quad 17.60$

$20 \quad 1.00$ SRSX25 $\quad 17.60$

$\begin{array}{lll}104 & 1.00 \text { SASX25 } & 17.60\end{array}$

$45 \quad 1.00$ SRSX25 17.60

$\begin{array}{lll}15 & 1.00 \text { SRS } \times 25 \quad 17.60\end{array}$

$\begin{array}{lll}17 & 1.00 \text { SRSX25 } & 17.60\end{array}$

$53 \quad 1.00$ SRSX25 17.60

$\begin{array}{lll}11 & 1.00 \text { SRS } \times 25 & 17.60\end{array}$

$\begin{array}{lll}10,080 & 1.00 \text { SRSX25 } & 17.60\end{array}$ $\begin{array}{lll}198 & 1.00 \text { SRS } 25 & 17.60\end{array}$

0
0
0
0
0
0
0
0
0
0
0
0
0
0
0
0
0
0
0
0
0

$\begin{array}{llll}18,673 & 17.60 & 0 & 422,800\end{array}$

$0 \quad 8,000$

SITE \#8, COOLING OPTION \#2

$\begin{array}{lllll}1,680 & 1.00 \text { SRSX01 } & 17.60 & 0 & \mathbf{1 , 2 0 0 , 0 0 0}\end{array}$

\section{$0 \quad 1.00$ SASX01}

$240,800 \quad 1.00$ SRSX25 $\quad 17.60$

$107,500 \quad 1.00$ SRS $\times 25 \quad 17.60$

$\begin{array}{lll}18 & 1.00 \text { SRS } \times 25 & 17.60\end{array}$

$180 \quad 1.00$ SRSX26 $\quad 17.10$

$384 \quad 1.00$ SRSX25 $\quad 17.60$

$\begin{array}{lll}320 & 1.00 \text { SRS } \times 25 & 17.60\end{array}$

$40000.00 \quad 80.000$

$\begin{array}{lr}0 & 1,200,000 \\ 0 & (5,620,000) \\ 0 & 33,368,000 \\ 0 & 0 \\ 0 & 38,000 \\ 0 & 0 \\ 0 & 136,000 \\ 0 & 160,000\end{array}$

200

480

1,000

4,800

6,200
300

2,800

292,800

0
11

11
125

150

$\begin{array}{r}169 \\ 370 \\ 120 \\ 1 \\ 683 \\ 2 \\ 1,232 \\ 127 \\ 127 \\ 616 \\ 92,928 \\ 109 \\ 25 \\ 445 \\ 616 \\ 348 \\ 1,836 \\ 799 \\ 271 \\ 304 \\ 924 \\ 201 \\ 177,408 \\ 3,485 \\ \hline\end{array}$
169
370
120
118
683
232
, 232
127
616
09
45
616
348
1,836
799
799
271
304
3,485

1,146

4,270
1,430

0

$\begin{array}{rr}700 & 924 \\ 0 & 201 \\ 720,000 & 177,408 \\ 12,600 & 3,485\end{array}$

$1,057,877$

328,613

0

$1,809,290$

$1,229,568$

$(5,620,000)$

$37,606,080$

$1,892,000$

38,317

4,078

142,758

165,632 
FILE: APTCOOL

PRoject NAME: PRoucCt NAME
ENGINEERING \& CONS “ UTION SERVICES DIVISION

SITE PROJEUT ESTIMATING

DETAIL LINE ITEMS
PAGE: 7

TIME: $08: 35: 58$

DATE O9-AUg-1996

AEPORT NAME: APT Detall WBS EXCEL FORMAT

PRICING: PRE 95 OR POST 94 RATES

CRAFT CONTRACT TOTAL

WBS TWC DESCRIPTION QUANTITY UOM MATL

UNIT $T$ TL ADJ

CONST.

ENGR'D

ENGR'D
EQUIP.

LABOR SERVICES

CosT

GROUP: NO APT GROUP IDENTIFIED

ACCOUNT CODE:

8673 102" IO PNEUMATIC PPE JOINT TEST

$8673102^{*} \times 36$ CONCRETE REDUCER

$8714102 \cdot 10$ GATE VALVE, FLG IALLOWANCE)

8317 42" CS PIPE. SCH 10

$831742^{\circ}$ TEE

$8317 \quad 42^{\circ} \mathrm{ELL} .90$

8317 42" FLANGE, WN

8714 42" GATE VALVE, FLG

8520 42. PIPE SUPPORT [ALLOWANCE]

4569 42. PIPE - PRIME \& PAINT - 120

8912 42" PIPE HYDROTEST

$831736^{\circ}$ CS PIPE, SCH 10

8317 36" TEE

$831736^{\circ}$ ELL, 90

8317 36. FLANGE, WN

$871436^{\circ}$ GATE VALVE, FLG

$871436^{\circ}$ CHECK VALVE, FLG

$852036^{\circ}$ PIPE SUPPORT

(ALLOWANCE! 4569 36. PIPE - PRIME \& PAINT
1300 LF

891236 " PIPE HYDROTEST

3211 MACHINE EXCAVATE FOR SITE

3212 HAND EXCAVATE FOR SITE

3221 FURNISH \& PLACE PIPE BEDDING SAND

3221 TRENCH BACKFILL \& COMPACTION

3216 HAUL \& DUMP (EXCESS)

4160 CONCAETE FOR PUMP PADS

4140 REBAR FOR FOR PUMP PAOS

4120 FORMWORK FOR PUMP PADS

4140 FUANISH FAB \& PLACE

COVERI GRATING

\begin{tabular}{|c|c|c|}
\hline \multirow[b]{2}{*}{$2,150.0 \mathrm{EA}$} & \multicolumn{2}{|c|}{ WBS 1.2.1.06 } \\
\hline & 0.00 & 2.000 \\
\hline $1.0 \mathrm{EA}$ & 4500.00 & 16.000 \\
\hline $4.0 \mathrm{EA}$ & 32000.00 & 64.000 \\
\hline $120.0 \mathrm{LF}$ & 102.00 & 1.600 \\
\hline $3.0 \mathrm{EA}$ & 2200.00 & 68.000 \\
\hline $4.0 \mathrm{EA}$ & 1300.00 & 48.000 \\
\hline $12.0 \mathrm{EA}$ & 1000.00 & 26.000 \\
\hline $4.0 \mathrm{EA}$ & 37000.00 & 48.000 \\
\hline $8.0 \mathrm{EA}$ & 100.00 & 30.000 \\
\hline $1,320.0 \mathrm{SF}$ & 0.60 & 0.100 \\
\hline $120.0 \mathrm{LF}$ & 0.00 & 0.600 \\
\hline $1,300.0 \mathrm{LF}$ & 95.00 & 1.500 \\
\hline $120.0 \mathrm{EA}$ & 2100.00 & 59.000 \\
\hline $6.0 \mathrm{EA}$ & 1200.00 & 42.000 \\
\hline $252.0 \mathrm{EA}$ & 940.00 & 24.000 \\
\hline $124.0 \mathrm{EA}$ & 35000.00 & 34.000 \\
\hline $4.0 \mathrm{EA}$ & 30000.00 & 34.000 \\
\hline $44.0 \mathrm{EA}$ & 75.00 & 25.000 \\
\hline $12,200,0 \mathrm{SF}$ & 0.60 & 0.100 \\
\hline $1,300.0 \mathrm{LF}$ & 0.00 & 0.368 \\
\hline $06,020.0 \mathrm{cr}$ & 0.00 & 0.030 \\
\hline $10,000.0 \mathrm{cr}$ & 0.00 & 4.000 \\
\hline $1,911.0 \mathrm{Cr}$ & 8.00 & 0.830 \\
\hline $46,733.0 \mathrm{cr}$ & 0.00 & 0.060 \\
\hline $27,999.0 \mathrm{cr}$ & 0.00 & 1.200 \\
\hline $20.0 \mathrm{cr}$ & 60.00 & 2.500 \\
\hline $1.0 \mathrm{TON}$ & 600.00 & 20.000 \\
\hline $164.0 \mathrm{SFCA}$ & 0.75 & 0.500 \\
\hline .05 & 8.35 & 0.093 \\
\hline
\end{tabular}

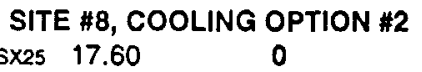

1.00 SRS $\times 25 \quad 17.60$

$\begin{array}{lll}256 & 1.00 \mathrm{SAS} \times 25 \quad 17.60\end{array}$

$192 \quad 1.00$ SRS $\times 25 \quad 17.60$

$204 \quad 1.00$ SAS $\times 25 \quad 17.60$

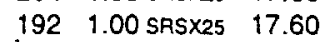

$\begin{array}{lll}312 & 1.00 \text { SRSX25 } & 17.60\end{array}$

1921.00 SASX25 17.60

$240 \quad 1.00$ SRSX25 17.60

$132 \quad 1.00$ SRSX $14 \quad 15.60$

$\begin{array}{lll}72 & 1.00 \text { SRS } \times 25 & 17.60\end{array}$

$\begin{array}{lll}1.950 & 1.00 \text { SRS } \times 25 & 17.60\end{array}$

$\begin{array}{ll}7,080 & 1.00 \text { SRSX25 } \quad 17.60\end{array}$

2521.00 SAS $\times 25 \quad 17.60$

$6,048 \quad 1.00$ SRSX25 $\quad 17.60$

$4,216 \quad 1.00$ SRS $\times 25 \quad 17.60$

$136 \quad 1.00$ SRSX25 $\quad 17.60$

$\begin{array}{lll}1,100 & 1.00 \text { SRSX25 } \quad 17.60\end{array}$

$\begin{array}{lll}1.220 & 1.00 \text { SRSX } 14 \quad 15.60\end{array}$

$\begin{array}{lll}478 & 1.00 \text { SRSX25 } & 17.60\end{array}$

$\begin{array}{lll}15,181 & 1.00 \text { SRSX05 } & 16.20\end{array}$

$40,000 \quad 1.00$ SRSX04 $\quad 11.80$

$1,586 \quad 1.00$ SRSX04 $\quad 11.80$

$\begin{array}{ll}14,804 & 1.00 \text { SRSX05 } 16.20\end{array}$

$33,599 \quad 1.00$ SRSX05 $\quad 16.20$

$\begin{array}{lll}50 & 1.00 \text { SRS } \times 10 & 12.20\end{array}$

$20 \quad 1.00$ SRSX08 $\quad 17.30$

821.00 SRS $\times 07 \quad 14.60$

$\begin{array}{lll}74 & 1.00 \text { SRS } \times 12 \quad 17.50\end{array}$

$0 \quad 4,500$

128,000

12,240

6,600

5,200

12,000

148,000

0

0

0

123,500

252,000

7,200
236,880

236,880

$4,340,000$

120,000

0

0

0

65,538

0

202,321

0

0
0
0

1,296

$======$

$=======$

WBS1.2.1.06 SITE \#8, COOLING OPTION \#2 SUBTOTAL

$\begin{array}{llll}484,866 \quad 6691 & 669,155 & 34,678,120\end{array}$

WBS 1.2.1.07

3211 MACHINE EXCAVATE FOR SITE

$12,024.0 \mathrm{CY}$

$0.00 \quad 0.030$

SITE \#8, COOLING OPTION \#3

3212 HANO EXCAVATE FOR SITE

$4,008.0 \mathrm{Cr}$

SITE $\# 8$, COOLING OPTI
1.00 SRSXO5 $16.20 \quad 11,062$

$16,032 \quad 1.00$ SASX04 11.80

0

0

$1 . \quad 0.00 \quad 4.000 \quad 16,032 \quad 1.00$ sasxo4 11.80

\begin{tabular}{|c|c|c|c|c|}
\hline$, 678,120$ & 37,103 & $8,200,107$ & 0 & $\begin{array}{r}43,584,486 \\
========\end{array}$ \\
\hline 0 & 0 & 5,844 & 0 & 16,906 \\
\hline 0 & 0 & 189,178 & 0 & 189,178 \\
\hline
\end{tabular}


FILE: APTCOOL

PROJECT NAME: PROucCT NAME
ENGINEERING \& CONS ' JCTION SERVICES DIVISION SITE PROJLUTT ESTIMATING

DETAIL LINE ITEMS
PAGE * 8

TIME: $08: 35: 58$

DATE 09-Aug-1996

PRICING: PRE 95 OR POST 94 RATES

REPORT NAME. APT Detail WBS EXCEL FORMAT

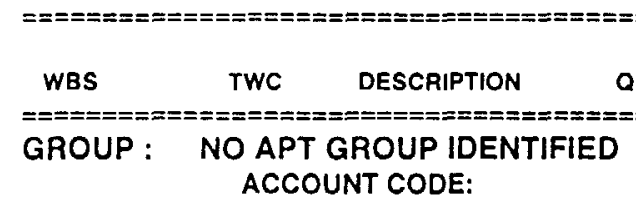

\section{ACCOUNT CODE}

\begin{tabular}{|c|c|}
\hline 3221 & $\begin{array}{l}\text { FURNISH \& PLACE PIPE } \\
\text { BEDDING SAND }\end{array}$ \\
\hline 3229 & $\begin{array}{l}\text { TRENCH BACKFILL } \\
\text { COMPACTION }\end{array}$ \\
\hline 3216 & HAUL \& DUMP (EXCESS) \\
\hline \multirow[t]{33}{*}{3720} & $\begin{array}{l}\text { 6. DIA WELL CASING W/ PUMP } \\
\text { (500 GPM } 15 \mathrm{HP})\end{array}$ \\
\hline & $\begin{array}{l}\text { WELL FIELD TANK } 123.5^{\circ} \text { DIA } \times \\
15.5^{\prime} \text { HIGH }-50000 \text { GAL] } \\
6^{*} \text { PIPE, STN STL }\end{array}$ \\
\hline & $\sigma^{*} E L L, 90$ \\
\hline & 6. FLANGE, WN \\
\hline & 6" GATE VALVE, FLG \\
\hline & 6. CHECK VALVE, FLG \\
\hline & 6. CONTAOL VALVE, FLG \\
\hline & 6. PIPE SUPPORT, STN STL. \\
\hline & 6* HYDROTEST \\
\hline & 6. PIPE, PVC \\
\hline & 6. MYOROTEST \\
\hline & 10. PIPE, PVC \\
\hline & 10 HYDROTEST \\
\hline & 18. PIPE, PVC \\
\hline & 18. HYDROTEST \\
\hline & $14^{\circ}$ PIPE, CS \\
\hline & $14^{\circ}$ TEE \\
\hline & $14^{\circ}$ ELL. 90 \\
\hline & 14. GATE VALVE, FLG \\
\hline & $14^{\circ}$ CHECK VALVE, FLG \\
\hline & 14' FLANGE, WN \\
\hline & $14^{*}$ PIPE SUPPORT, CS \\
\hline & $18^{*} \times 14^{*}$ REDUCER \\
\hline & $14^{\circ}$ HYDROTEST \\
\hline & $\begin{array}{l}\text { 14" PIPE - PRIME \& PAINT - } 10 \\
\text { LF }\end{array}$ \\
\hline & $16^{\circ}$ PIPE, CS \\
\hline & $16^{*}$ TEE \\
\hline & $16^{\circ}$ ELL. 90 \\
\hline & $16^{\circ}$ GATE VALVE, FLG \\
\hline & 16. FLANGE, WN \\
\hline & 16. PIPE SUPPORT, CS \\
\hline & $16^{\circ}$ HYOROTEST \\
\hline & $\begin{array}{l}\text { 16. PIPE - PRIME \& PAINT } \\
\text { LF }\end{array}$ \\
\hline
\end{tabular}

\begin{tabular}{|c|c|c|}
\hline \multirow[b]{2}{*}{$1,629.0 \mathrm{cY}$} & \multicolumn{2}{|c|}{ WBS 1.2.1.07 } \\
\hline & 8.00 & 0.830 \\
\hline $13.139 .0 \mathrm{cr}$ & 0.00 & 0.060 \\
\hline $3,360.0 \mathrm{cY}$ & 0.00 & 1.200 \\
\hline 18.0 EA & 0.00 & 0.000 \\
\hline $1.0 \mathrm{EA}$ & 0.00 & 0.000 \\
\hline $180.0 \mathrm{LF}$ & 32.00 & 0.390 \\
\hline $36.0 \mathrm{EA}$ & 95.00 & 9.400 \\
\hline $144.0 \mathrm{EA}$ & 167.00 & 9.200 \\
\hline $36.0 \mathrm{EA}$ & 3000.00 & 3.100 \\
\hline $18.0 \mathrm{EA}$ & 2100.00 & 3.100 \\
\hline $18.0 \mathrm{EA}$ & 19000.00 & 6.000 \\
\hline $36.0 \mathrm{EA}$ & 75.00 & 16.000 \\
\hline $180.0 \mathrm{LF}$ & 0.00 & 0.250 \\
\hline $1,800.0 \mathrm{LF}$ & 1.60 & 0.140 \\
\hline $1,800.0 \mathrm{LF}$ & 0.00 & 0.150 \\
\hline $24,000.0 \mathrm{LF}$ & 12.20 & 0.150 \\
\hline $24,000.0 \mathrm{LF}$ & 0.00 & 0.310 \\
\hline $6,000.0 \mathrm{LF}$ & 13.50 & 0.250 \\
\hline $6,000.0 \mathrm{LF}$ & 0.00 & 0.250 \\
\hline $10.0 \mathrm{LF}$ & 25.80 & 0.830 \\
\hline $1.0 \mathrm{EA}$ & 430.00 & 23.000 \\
\hline $2.0 \mathrm{EA}$ & 280.00 & 15.000 \\
\hline $2.0 \mathrm{EA}$ & 7500.00 & 5.100 \\
\hline $2.0 \mathrm{EA}$ & 4800.00 & 5.100 \\
\hline 10.0 EA & 220.00 & 6.200 \\
\hline $4.0 \mathrm{EA}$ & 40.00 & 12.000 \\
\hline $1.0 \mathrm{EA}$ & 260.00 & 17.000 \\
\hline $10.0 \mathrm{LF}$ & 0.00 & 0.380 \\
\hline $40.0 \mathrm{SF}$ & 0.70 & 0.108 \\
\hline $10.0 \mathrm{LF}$ & 30.80 & 0.890 \\
\hline $1.0 \mathrm{EA}$ & 520.00 & 26.000 \\
\hline $2.0 \mathrm{EA}$ & 380.00 & 18.000 \\
\hline $2.0 \mathrm{EA}$ & 10200.00 & 5.900 \\
\hline $6.0 \mathrm{EA}$ & 350.00 & 6.900 \\
\hline 4.0 EA & 50.00 & 15.000 \\
\hline $10.0 \mathrm{LF}$ & 0.00 & 0.440 \\
\hline $40.0 \mathrm{SF}$ & 0.60 & 0.100 \\
\hline 0.0 & & \\
\hline $20.0 \mathrm{LF}$ & 51.50 & 0.950 \\
\hline $7.0 \mathrm{EA}$ & 480.00 & 12.700 \\
\hline
\end{tabular}

$831518^{\circ}$ PIPE, CS. STD

8315 19. FLANGE, WN, 150"

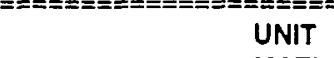

UNIT

TTL ADJ

ADJ
CONST.

EQUIP.

ENGR'D

CRAFT

CONTRACT

SERVICES

TOTAL

COST

$=$

w

\section{SITE \#8, COOLING OPTION \#3}

$\begin{array}{llll}1,352 & 1.00 \text { SASX04 } 11.80 \quad 0\end{array}$

$\begin{array}{lll}788 & 1.00 \text { SRSX05 } \quad 16.20\end{array}$

10,774

$4,032 \quad 1.00$ SRSX05 $\quad 16.20$

$$
01.00
$$

01.00

$70 \quad 1.00$ SRSX25 $\quad 17.60$
3.00

$338 \quad 1.00$ SRSX25 $\quad 17.60$

$1,325 \quad 1.00$ SRS $\times 25 \quad 17.60$

$\begin{array}{lll}112 & 1.00 \text { SRSX25 } \quad 17.60\end{array}$

$\begin{array}{lll}56 & 1.00 \mathrm{SRS} \times 25 \quad 17.60\end{array}$

$\begin{array}{lll}108 & 1.00 \text { SRSX25 } & 17.60\end{array}$

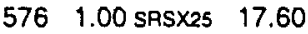

$45 \quad 1.00$ SASX25 17.60

$\begin{array}{lll}252 & 1.00 \text { SASX25 } & 17.60\end{array}$

$270 \quad 1.00$ SRS $\times 25 \quad 17.60$

$3,600 \quad 1.00$ SRSX25 $\quad 17.60$

$7.440 \quad 1.00$ SRSX25 $\quad 17.60$

$\begin{array}{lll}1,500 \quad 1.00 \text { SRSX25 } \quad 17.60 & 0\end{array}$

$\begin{array}{lll}1,500 & 1.00 \text { SASX25 } \quad 17.60\end{array}$

$\begin{array}{lll}8 & 1.00 \text { SRS } \times 25 & 17.60\end{array}$

$23 \quad 1.00$ SRSX25 17.60

$30 \quad 1.00$ SRSX25 17.60

$\begin{array}{lll}10 & 1.00 \text { SASX25 } \quad 17.60\end{array}$

$10 \quad 1.00$ SRSX25 17.60

$\begin{array}{lll}62 & 1.00 \text { SRSX25 } & 17.60\end{array}$

$48 \quad 1.00$ SASX25 $\quad 17.60$

171.00 SASX25 17.60

$4 \quad 1.00$ SRSX25 17.60

$4 \quad 1.00$ SRSX14 15.60

$\begin{array}{lll}9 & 1.00 \text { SASX25 } \quad 17.60\end{array}$

$\begin{array}{lll}26 & 1.00 \text { SRSX25 } & 17.60\end{array}$

$36 \quad 1.00$ SASX25 $\quad 17.60$

$12 \quad 1.00$ SRSX25 17.60

$41 \quad 1.00$ SASX25 $\quad 17.60$

$\begin{array}{ll}60 & 1.00 \text { SASX25 } \quad 17.60\end{array}$

$4 \quad 1.00$ SAS $\times 25 \quad 17.60$

$4 \quad 1.00$ SRSX14 15.60

$$
0 \quad 1.00
$$

$\begin{array}{lll}19 & 1.00 \text { SAS } \times 25 \quad 17.60\end{array}$

$89 \quad 1.00$ SRSX25 17.60

0
0
0
0
0
0
0
108,000
37,800
342,000
0
0
0
0
0
0
0
0
0
0
0
15,000
9,600
0
0
0
0
0
0
0
0
0
0
0
0
0

15,954
12,771
65,318
0
0
1,236
5,956
23,316
1,964
982
1,901
10,138
792
4,435
4,752
63,360
130,944
26,400
26,400
146
405
528
180
180
1,091
845
299
67
67
157
458
334
1,565
634
208
729
1,056
77
62
28,986

23,545

65,318 900,000

55,000

6,996 9,376

47,364

09,964

38,782

343,901

12,838
792

7,315

7,315
4,752

356,160

130,944

107,400

26,400

404

835
1,088

15,180

9,780

3,291

1,005
559

67

95

465

978
1,394

20,608

2,829

1,256

86

1,364 4,925 
FILE: APTCOOL'

PROJECT NAME: PROucCT NAME
ENGINEERING \& CONS - ICTION SERVICES DIVISION

SITE PROJECT ESTIMATING

DETAIL LINE ITEMS
PAGE 9

TIME: 08:35:58

DATE 09-Aug-1996

PRICING: PRE 95 OR POST 94 RATES

REPORT NAME: APT Detall WBS EXCEL FORMAT

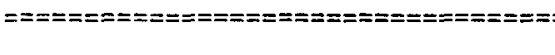

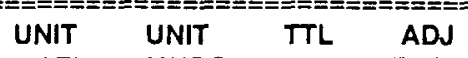

TWC DESCRIPTION

QUANTIYY UOM
MATL

MHRS

$==:====$
coNST.

ENGR'D

CRAFT

CRAFT CONTRACT

TOTAL

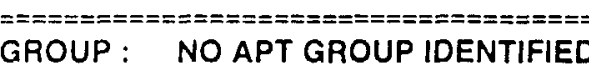
ACCOUNT CODE:

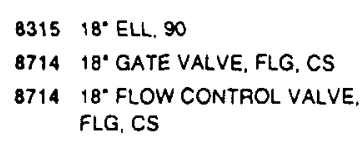

\begin{tabular}{rrr} 
& \multicolumn{2}{c}{ WBS 1.2 .1 .07} \\
$2.0 \mathrm{EA}$ & 490.00 & 20.500 \\
$2.0 \mathrm{EA}$ & 12400.00 & 6.700 \\
$1.0 \mathrm{EA}$ & 30000.00 & 15.000 \\
& & \\
$7.0 \mathrm{EA}$ & 68.00 & 6.600
\end{tabular}

SITE \#8, COOLING OPTION \#3

$871418^{\circ}$ FLOW CONTROL VALVE,

$831318^{\circ}$ BOLT.UP W/B8G SET

7.0 EA $\quad 68.00 \quad 6.600$

WBS1.2.1.07 SITE \#8, COOLING OPTION \#3 SUBTOTAL

WBS 1.2.1.08

1310 COOLING WATER PUMPS [50000GPM $\odot 2250 \mathrm{HP}$ ]

1400 ADJUSTMENT FOR COOLING EQUIPMENT (DELETE CT)

$867384^{\circ}$ ID CONCRETE PIPE

8673 B4. ID PIPE JOINT [GROUT \& GASKET $8.25^{\circ} O 0 \bigcirc 25.9$ LF

$394084^{\circ}$ CONCRETE PIPE, D\&R $8^{\circ}$

$86733^{84^{\circ}}$ D F FLANGE ADAPTERS
$87144^{\circ}$ 84 IO GATE VALVE, FLG (ALLOWANCE)

$394084^{\circ}$ CONCRETE PIPE D \& A

$86733^{\circ} 4^{\circ}$ CONCRETE PIPE CAP

$891284^{\circ}$ IO PNEUMATIC PIPE JOINT TEST

$867378^{\circ} 10$ CONCRETE PIPE

8673 78. ID PIPE JOINT [GROUT \& GASKET-7.5 023.6 LF

$867378^{\circ}$ ID CONCRETE TIE-IN

$891278^{\circ}$ ID PNUEMATIC PIPE JOINT

8317 42* CS PIPE, SCH 10

8317 42" TEE

$831742^{\circ}$ ELL, 90

$831742^{\circ}$ FLANGE, WN

8714 42" GaTe VALVE. FLG

8520 42* PIPE SUPPOAT [ALLOWANCE] 4569 42" PIPE - PRIME \& PAINT - 120
LF

8912 42. PIPE HYDROTEST

$331736^{\circ} \mathrm{CS}$ PIPE, SCH 10

8317 36" TEE

$831736^{\circ}$ ELL, 90

$831736^{\circ}$ FLANGE, WN

0714 36. GATE VALVE, FLG

$871436^{\prime}$ CHECK VALVE, FLG

\begin{tabular}{|c|c|c|c|c|c|}
\hline \multirow[b]{2}{*}{$4.0 \mathrm{EA}$} & \multicolumn{3}{|c|}{ WBS 1.2.1.08 } & \multicolumn{2}{|c|}{ SITE \#8, C } \\
\hline & 400000.00 & 720.000 & 2,880 & 1.00 SPSX01 & 17.60 \\
\hline (10.0)EA & & & 0 & 1.00 & \\
\hline $300.0 \mathrm{LF}$ & 245.00 & 1.400 & 126,420 & 1.00 SRS $\times 25$ & 17.60 \\
\hline $258.0 \mathrm{EA}$ & 0.00 & 42.000 & 94,836 & 1.00 SRS $\times 25$ & 17.60 \\
\hline 2.0EA & 1180.00 & 180.000 & 360 & $1.00 \mathrm{SRS} \times 26$ & 17.10 \\
\hline $18.0 \mathrm{EA}$ & 8000.00 & 54.000 & 972 & 1.00 SRS $\times 25$ & 17.60 \\
\hline $9.0 \mathrm{EA}$ & 28000.00 & 56.000 & 504 & 1.00 SAS $\times 25$ & 17.60 \\
\hline $48.0 \mathrm{LF}$ & 0.00 & 2.600 & 125 & $1.00 \mathrm{SRS} \times 25$ & 17.60 \\
\hline $8.0 \mathrm{EA}$ & 8800.00 & 42.000 & 336 & 1.00 SRS $\times 25$ & 17.60 \\
\hline $258.0 \mathrm{EA}$ & 0.00 & 1.800 & 4,064 & $1.00 \mathrm{SPS} \times 25$ & 17.60 \\
\hline $600.0 \mathrm{LF}$ & 233.00 & 1.400 & 840 & $1.00 \mathrm{SRS} \times 25$ & 17.60 \\
\hline $15.0 \mathrm{EA}$ & 0.00 & 39.000 & 585 & 1.00 SAS $\times 25$ & 17.60 \\
\hline $4.0 \mathrm{EA}$ & 950.00 & 170.000 & 680 & 1.00 SRS $\times 25$ & 17.60 \\
\hline $15.0 \mathrm{EA}$ & 1.60 & 1.600 & 24 & 1.00 SRS $\times 25$ & 17.60 \\
\hline $120.0 \mathrm{LF}$ & 102.00 & 1.600 & 192 & 1.00 SRS $\times 25$ & 17.60 \\
\hline $3.0 \mathrm{EA}$ & 2200.00 & 68.000 & 204 & 1.00 SRS $\times 25$ & 17.60 \\
\hline 4.0 EA & 1300.00 & 48.000 & 192 & 1.00 SRSX 25 & 17.60 \\
\hline $12.0 \mathrm{EA}$ & 1000.00 & 26.000 & 312 & 1.00 SRS $\times 25$ & 17.60 \\
\hline $4.0 \mathrm{EA}$ & 37000.00 & 48.000 & 192 & 1.00 SRSX25 & 17.60 \\
\hline $8.0 \mathrm{EA}$ & 100.00 & 30.000 & 240 & $1.00 \mathrm{SAS} \times 25$ & 17.60 \\
\hline $320.0 \mathrm{SF}$ & 0.60 & 0.100 & 132 & 1.00 SRSXt4 & 15.60 \\
\hline $120.0 \mathrm{LF}$ & 0.00 & 0.600 & 72 & $1.00 \mathrm{SRS} \times 25$ & 17.60 \\
\hline $300.0 \mathrm{LF}$ & 95.00 & 1.500 & 1,950 & 1.00 SRSX25 & 17.60 \\
\hline $120.0 \mathrm{EA}$ & 2100.00 & 59.000 & 7,080 & 1.00 SRSX2S & 17.60 \\
\hline $6.0 \mathrm{EA}$ & 1200.00 & 42.000 & 252 & 1.00 SASX25 & 17.60 \\
\hline $252.0 \mathrm{EA}$ & 940.00 & 24.000 & 6,048 & $1.00 \mathrm{SRS} \times 25$ & 17.6 \\
\hline $124.0 \mathrm{EA}$ & 35000.00 & 34.000 & 4,216 & 1.00 SRSX2S & 17.6 \\
\hline & & 34000 & & $100585 \times 25$ & \\
\hline
\end{tabular}

$\begin{array}{lll}41 & 1.00 \text { SRSX25 } & 17.60 \\ 13 & 1.00 \text { SRS } \times 25 & 17.60 \\ 15 & 1.00 \text { SRSX25 } & 17.60\end{array}$

0
0
0
0

0

$46 \quad 1.00$ SASX25 $\quad 17.60$

0

\section{4,800}

30,000

476

21,836

532,800

494,094

\section{8 , COOLING OPTION \#4}

$1,600,000$

\begin{tabular}{|c|c|}
\hline 0 & 50,688 \\
\hline 0 & 0 \\
\hline $\begin{array}{l}0 \\
0\end{array}$ & $\begin{array}{l}2,224,992 \\
1,669,114\end{array}$ \\
\hline 2,000 & 6,156 \\
\hline $\begin{array}{l}0 \\
0\end{array}$ & $\begin{array}{r}17,107 \\
8,870\end{array}$ \\
\hline $\begin{array}{l}0 \\
0 \\
0\end{array}$ & $\begin{array}{r}2,196 \\
5,914 \\
71,533\end{array}$ \\
\hline $\begin{array}{l}0 \\
0\end{array}$ & $\begin{array}{l}14,784 \\
10,296\end{array}$ \\
\hline $\begin{array}{l}0 \\
0\end{array}$ & $\begin{array}{r}11,968 \\
422\end{array}$ \\
\hline 0 & 3,379 \\
\hline 0 & 3,590 \\
\hline 0 & 3,379 \\
\hline 0 & 5,491 \\
\hline 0 & 3,379 \\
\hline 800 & 4,224 \\
\hline 792 & 2,059 \\
\hline 0 & 1,267 \\
\hline 0 & 34,320 \\
\hline 0 & 124,608 \\
\hline 0 & 4,435 \\
\hline 0 & 106,445 \\
\hline 0 & 74,202 \\
\hline 0 & 2,394 \\
\hline
\end{tabular}

\begin{tabular}{|c|c|}
\hline 0 & 50,688 \\
\hline 0 & 0 \\
\hline $\begin{array}{l}0 \\
0\end{array}$ & $\begin{array}{l}2,224,992 \\
1,669,114\end{array}$ \\
\hline 2,000 & 6,156 \\
\hline $\begin{array}{l}0 \\
0\end{array}$ & $\begin{array}{r}17,107 \\
8,870\end{array}$ \\
\hline $\begin{array}{l}0 \\
0 \\
0\end{array}$ & $\begin{array}{r}2,196 \\
5,914 \\
71,533\end{array}$ \\
\hline $\begin{array}{l}0 \\
0\end{array}$ & $\begin{array}{l}14,784 \\
10,296\end{array}$ \\
\hline $\begin{array}{l}0 \\
0\end{array}$ & $\begin{array}{r}11,968 \\
422\end{array}$ \\
\hline 0 & 3,379 \\
\hline 0 & 3,590 \\
\hline 0 & 3,379 \\
\hline 0 & 5,491 \\
\hline 0 & 3,379 \\
\hline 800 & 4,224 \\
\hline 792 & 2,059 \\
\hline 0 & 1,267 \\
\hline 0 & 34,320 \\
\hline 0 & 124,608 \\
\hline 0 & 4,435 \\
\hline 0 & 106,445 \\
\hline 0 & 74,202 \\
\hline 0 & 2,394 \\
\hline
\end{tabular}

$(5,620,000)$

$22,123,500$

360

\begin{tabular}{|c|c|}
\hline 0 & 50,688 \\
\hline 0 & 0 \\
\hline $\begin{array}{l}0 \\
0\end{array}$ & $\begin{array}{l}2,224,992 \\
1,669,114\end{array}$ \\
\hline 2,000 & 6,156 \\
\hline $\begin{array}{l}0 \\
0\end{array}$ & $\begin{array}{r}17,107 \\
8,870\end{array}$ \\
\hline $\begin{array}{l}0 \\
0 \\
0\end{array}$ & $\begin{array}{r}2,196 \\
5,914 \\
71,533\end{array}$ \\
\hline $\begin{array}{l}0 \\
0\end{array}$ & $\begin{array}{l}14,784 \\
10,296\end{array}$ \\
\hline $\begin{array}{l}0 \\
0\end{array}$ & $\begin{array}{r}11,968 \\
422\end{array}$ \\
\hline 0 & 3,379 \\
\hline 0 & 3,590 \\
\hline 0 & 3,379 \\
\hline 0 & 5,491 \\
\hline 0 & 3,379 \\
\hline 800 & 4,224 \\
\hline 792 & 2,059 \\
\hline 0 & 1,267 \\
\hline 0 & 34,320 \\
\hline 0 & 124,608 \\
\hline 0 & 4,435 \\
\hline 0 & 106,445 \\
\hline 0 & 74,202 \\
\hline 0 & 2,394 \\
\hline
\end{tabular}

0

0

360

144,000

252,000

0
70,400
0

139,800

0

24

12,240

6,600

5,200

12,000

148,000

0

0
123,500

25,000
7,200

236,880

$4,340,000$

120,000

$136 \quad 1.00$ SRS $\times 25 \quad 17.60$

$1,650,688$

$(5,620,000)$

$24,348,492$

$1,669,114$

8,516

161,107 260,870

2,196

76,314

71,533

154,584

10,296

15,768

446

15,619

10,190

8,579

151,379

5,024

2,851

1,267

157,820

376,608

11,635
343,325

$4,414,202$

122,394 
FILE: APTCOOL

PRoject Name: PRouéct NAME
ENGINEERING \& CONE JUTION SERVICES DIVISION

SITE PROJECT ESTIMATING

DETAIL LINE ITEMS
PAGE " 10

TIME: $08: 35: 58$

DATE 09-Aug-1996

PRICING: PRE 95 OR POST 94 RATES

REPORT NAME: APT DEtail WBS EXCEL FORMAT

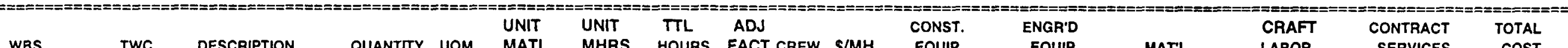

WBS TWC DESCRIPTION QUANTITY UOM MATL MHRS HOURS FACT CREW \$MH EQUIP.

GROUP : NO APT GROUP IDENTIFIED

ACCOUNT CODE:

$852036^{\circ}$ PIPE SUPPORT [ALLOWANCE]

$456936^{\circ}$ PIPE - PRIME \& PAINT 300 LF

$891236^{\circ}$ PIPE HYOROTEST

3211 MACHINE EXCAVATE FOR

DANOEAVATE FOR SITE FURNISH \& PLACE PIPE BEDDING SAND

3221 TRENCH BACKFIL COMPACTION

3216 HAUL \& DUMP (EXCESS)

4160 CONCRETE PUMP PADS

4140 REBAR FOR PUMP PADS

4120 FORMWORK FOR PUMP PADS

4140 FUANISH FAB \& PLACE

COVER/ GRATING

\begin{tabular}{rrr} 
& \multicolumn{2}{c}{ WBS 1.2 .1 .08} \\
$44.0 \mathrm{EA}$ & 75.00 & 25.000 \\
$12,200.0 \mathrm{SF}$ & 0.60 & 0.100 \\
$1,300.0 \mathrm{LF}$ & 0.00 & 0.368 \\
$403,887.0 \mathrm{Cr}$ & 0.00 & 0.030 \\
$4,600.0 \mathrm{CY}$ & 0.00 & 4.000 \\
$17,167.0 \mathrm{Cr}$ & 8.00 & 0.830 \\
$211,554.0 \mathrm{Cr}$ & 0.00 & 0.060 \\
$230.473 .0 \mathrm{Cr}$ & 0.00 & 1.200 \\
$20.0 \mathrm{Cr}$ & 60.00 & 2.500 \\
$1.0 \mathrm{rON}$ & 600.00 & 20.000 \\
$164.0 \mathrm{SFCA}$ & 0.75 & 0.500 \\
$800.0 \mathrm{SF}$ & 8.35 & 0.093
\end{tabular}

SITE \#8, COOLING OPTION \#4

$\begin{array}{ll}1,220 & 1.00 \text { SRSX } 14 \quad 15.60\end{array}$

$478 \quad 1.00$ SRS $\times 25 \quad 17.60$

$\begin{array}{rrrr}12,117 & 1.00 \text { SRSX05 } & 16.20 & 371,576\end{array}$

$\begin{array}{lll}18,400 & 1.00 \text { SAS } \times 04 \quad 11.80\end{array}$

$14,249 \quad 1.00$ SRSX04 11.80

$12,693 \quad 1.00$ SRSXOS $\quad 16.20$

$276.568 \quad 1.00$ SRSX05 16.20

$\begin{array}{lll}50 & 1.00 \text { SRSX } \times 10 & 12.20\end{array}$

$20 \quad 1.00$ SRSX08 17.30

821.00 SRS $\times 07 \quad 14.60$

$\begin{array}{ll}74 & 1.00 \text { SRSX } \times 12 \quad 17.50\end{array}$

LING OPTION
0
0
0
371,576
0
0

173,474

1,296
0
0
0
0

LABOR SERVICES

COST

WBS 1.2.1.08 SITE \#8, COOLING OPTION \#4 SUBTOTAL 1420 COOLING TOWER, 3 CELL
150 HP FAN - 56MW

$\begin{array}{lll}\text { 1.06.05.04.01 } & 1420 \text { COOLING TOWER, } 3 \text { CELL } \\ & \text { 150 HP FAN - 56MW } \\ \text { 1.06.05.04.01 } & 1310 \text { CW SUPPLY PUMP, } 12000\end{array}$

$\begin{array}{ll}\text { 1.06.05.04.01 } & 1420 \text { COOLING TOWER, } 3 \text { CELL } \\ \text { 150 HP FAN - 56MW } \\ \text { 1.05.05.04.01 } & 1310 \text { CW SUPPLY PUMP, } 12000 \\ & \text { GPM Q 400 HP }\end{array}$

$831336^{\circ}$ PIPE CS, STO

$831336^{\circ}$ TEE

$831336^{\circ} E L, 90$

$831336^{\circ}$ FLANGE, WN

8313 36. VALVES, FLG

8313 18. PIPE, CS, STD

$831318^{\circ}$ TEE

$831318^{\circ} \mathrm{ELL}, 90$

8313 18" FLANGE, WN

8313 18. VALVES. FLG

8912 HYDROTEST

4140 BUILOING FOR HOUSING EOT

4120 FORMWORK FOR HOUSING EQT

1.06 .05 .04 .01

4140 REBAR FOR HOUSING EOT

1.05.03.04.03.01 4160 CONCRETE FOR HOUSING

4120 FOR

1.05.03.04.03.01 4120 FORMWK/EOT FOUND. \&
HEAT EXCH.

1.05.03.04.03.01 4140 REBAR/ EQT FOUNDATION \& HEAT EXCH. $\begin{array}{llr}1.0 \mathrm{EA} & 0.00 \quad 0.000\end{array}$

3.0 EA $\quad 180000.00 \quad 180.000$

$\begin{array}{lll}950.0 \mathrm{LF} & 99.75 & 1.500\end{array}$

$10.0 \mathrm{EA} \quad 2205.00 \quad 59.000$

$20.0 \mathrm{EA} \quad 1260.00 \quad 42.000$

$\begin{array}{lll}26.0 \mathrm{EA} & 987.00 \quad 24.000\end{array}$

10.0 EA $\quad 36750.00 \quad 34.000$

$\begin{array}{lll}3,100.0 \mathrm{LF} & 51.50 & 0.950\end{array}$

$\begin{array}{lll}8.0 \mathrm{EA} & 850.00 \quad 29.200\end{array}$

$\begin{array}{lll}15.0 \mathrm{EA} & 490.00 \quad 20.500\end{array}$

$20.0 \mathrm{EA} \quad 480.00 \quad 12.700$

$\begin{array}{lll}6.0 \mathrm{EA} & 12400.00 \quad 6.600\end{array}$

$\begin{array}{lll}4,050.0 \mathrm{LF} & 0.00 & 0.480\end{array}$

$\begin{array}{lll}12,000.0 \mathrm{SF} & 35.00 & 1.000\end{array}$

$1,200.0 \mathrm{SF}$

$22.0 \mathrm{TN}$

$444.0 \mathrm{CY}$

$2,040.0 \mathrm{SF}$

$15.0 \mathrm{TN}$

$\begin{array}{rr}600.00 & 20.000 \\ 62.00 & 1.500\end{array}$

$0.75 \quad 1.000$

$600.00 \quad 20.000$

$$
\text { HEAT EXCH. }
$$

$====$

$=$

(1)

WBS 1.2.2.1

$2945 \quad 1.00$ SRSX25 17.60

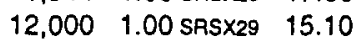

$\begin{array}{lll}1,200 & 1.00 \text { SASX07 } 14.60\end{array}$

$2,040 \quad 1.00$ SASX07 $\quad 14.60$

\section{0,895}

16.56

\section{- 100 CASE 10 - OPTION \#1}

$540 \quad 1.00$ SRSX0: 17.60

$\begin{array}{lll}1.425 & 1.00 \text { SRSX25 } & 17.60\end{array}$

$\begin{array}{lll}590 & 1.00 \text { SAS } \times 25 & 17.60\end{array}$

$840 \quad 1.00$ SASX25 $\quad 17.60$

$\begin{array}{lll}624 & 1.00 \text { SRS } \times 25 \quad 17.60\end{array}$

$\begin{array}{lll}340 & 1.00 \text { SAS } \times 25 \quad 17.60\end{array}$

$234 \quad 1.00$ SAS $\times 25 \quad 17.60$

$308 \quad 1.00$ SRSX25 17.60

$254 \quad 1.00$ SASX25 17.60

$40 \quad 1.00$ SASX25 17.60

$\begin{array}{lll}1.944 \quad 1.00 \text { SRSX25 } & 17.60\end{array}$

$\begin{array}{lll}440 \quad 1.00 \text { SRSXO8 } \quad 17.30 & 0\end{array}$

$\begin{array}{ll}666 & 1.00 \text { SASX } 10 \quad 12.20\end{array}$

$546,346 \quad 23,977,504$

n

540,000

$300 \quad 1.00$ SASX08 $\quad 17.30$

3,300
7,320
0
0
0
137,336
0
0
1,200
600
123
6,680

19,032
8,420
196,289

196,289

217,120

168,134

205,630

$4,480,395$

80,395
610

346
1,197

1,302

160,151

160,151

$9,785,049$

0

94,763

22,050

25,200

25,662

367,500

159,650

159,650
6,800

6,800
7,350

9,600

74,400

0

420,000

0,000
900

13,200

27,528

1,530

9,000

0

22,660

26,352

8,420
567,865

217,120

305,470

379,105

,480,395

1,810
946

1,320

9,278

$=$

$======2$

$N$ 
FILE: APTCOOI

PROJect NAME PRuucCt NAME
ENGINEERING \& CONS UUTION SERVICES DIVISION

SITE PROJECT ESTIMATING

DETAIL LINE ITEMS
PAGE 11

TIME: $08: 35: 58$

DATE 09-AUg-1996

PRICING: PRE 95 OR POST 94 RATES

REPORT NAME: APT Detail WBS EXCEL FORMAT

$===========0$

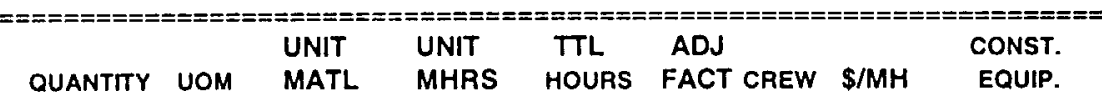

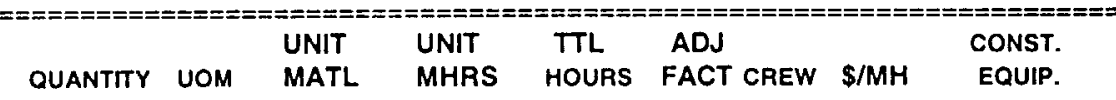
$===================================$
GROUP : NOAPT GROUP IDENTIFIED
ACCOUNT CODE:

\title{
ACCOUNT CODE:
}

1.05.03.04.03.01 4160 CONCRETE EOT

FOUNDATION \& HEAT EXH

1.05.03.04.03.01 4160 SHIELDING WALLS

1.05.03.04.03.01 3211 EXCAVATE FOR SLAB COOLING TOWER \& PUMP
PADS

1.05.03.04.03.01 3212 FORMWORK FOR COOLING TOWER \& PUMP PADS

1.05.03.04.03.01 4140 REBAR/CHILLER COOUNG TOWER \& PUMP PADS 1.05.03.04.03.01 4160 CONCAETE FOR COOLING
TOWEA \& PUMP PADS

\begin{tabular}{lrr} 
& \multicolumn{2}{c}{ WBS 1.2 .2 .1} \\
$444.0 \mathrm{CY}$ & 62.00 & 1.500 \\
$175.0 \mathrm{CY}$ & 300.00 & 12.000 \\
$500.0 \mathrm{CY}$ & 0.00 & 0.100 \\
& & \\
$540.0 \mathrm{CY}$ & 0.75 & 1.000 \\
$26.0 \mathrm{TN}$ & 600.00 & 20.000 \\
$520.0 \mathrm{CY}$ & 62.00 & 1.500
\end{tabular}

CASE 10 - OPTION \#1

$\begin{array}{lll}666 & 1.00 \text { SRSX10 } \quad 12.20\end{array}$

$\begin{array}{lll}2.100 & 1.00 \text { SASX13 } & 16.20\end{array}$

$\begin{array}{lll}50 & 1.00 \text { SRSX05 } & 16.20\end{array}$

$540 \quad 1.00$ SRSX07 $\quad 14.60$

$\begin{array}{lll}520 & 1.00 \text { SRSXOB } \quad 17.30\end{array}$

$\begin{array}{lll}780 & 1.00 \text { SRSX10 } & 12.20\end{array}$

$\# 1$
0
0
0
0
0

ENGR'D

ENGR'D

CRAFT

MAT'L

LABOR

$\begin{array}{cc}\text { CONTRACT } & \text { TOTAL } \\ \text { SERVICES } & \text { COST }\end{array}$

WBS1.2.2.1 CASE 10. OPTION\#1 SUBTOTAL

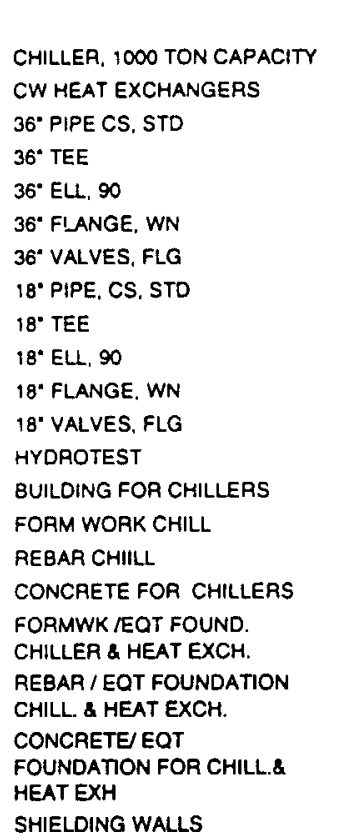

$2.0 \mathrm{EA}$
$6.0 \mathrm{EA}$
$950.0 \mathrm{LF}$
$10.0 \mathrm{EA}$
$20.0 \mathrm{EA}$
0.0
0.0
$4,150.0 \mathrm{LF}$
$10.0 \mathrm{EA}$
$20.0 \mathrm{EA}$
$26.0 \mathrm{EA}$
$10.0 \mathrm{EA}$
$5,100.0 \mathrm{LF}$
$21,500.0 \mathrm{SF}$
$1,975.0 \mathrm{SF}$
$40.0 \mathrm{TN}$
$800.0 \mathrm{CY}$
$23,880.0 \mathrm{SF}$
$32.0 \mathrm{TN}$
$978.0 \mathrm{CY}$
$\begin{array}{rr}\text { WBS } & 1.2 .2 .2 \\ 0.00 & 0.000 \\ 100000.00 & 72.000\end{array}$

31,385

15.81

0

0
0
0
0
0
0

$== \pm=:===$

\begin{tabular}{rrrrrr}
31,385 & & 15.81 & 0 & 540,000 & 1,393 \\
& \multicolumn{5}{c}{ CASE 10. OPTION \#2 } \\
0 & 1.00 & & 0 & 0 & \\
432 & 1.00 SRSX01 & 17.60 & 0 & $12,600,000$ & 0 \\
1,425 & 1.00 SRSX25 & 17.60 & 0 & 0 & \\
590 & 1.00 SASX25 & 17.60 & 0 & 0 &
\end{tabular}

$2205.00 \quad 59.000$

$1260.00 \quad 42.000$

$590 \quad 1.005 \mathrm{~A}$

$\begin{array}{lll}840 & 1.00 \text { SAS } \times 25 & 17.60\end{array}$

01.00 SRS $\times 25$

o 1.00 SRS $\times 25$

$3,943 \quad 1.00$ SRSX25 $\quad 17.60$

$292 \quad 1.00$ SRSX25 $\quad 17.60$

$\begin{array}{rr}51.50 & 0.950\end{array}$

$\begin{array}{ll}850.00 & 29.200 \\ 490.00 & 20.500\end{array}$

$480.00 \quad 12.700$

$12400.00 \quad 6.600$

$\begin{array}{lll}410 & 1.00 \text { SRSX25 } \quad 17.60\end{array}$

$330 \quad 1.00$ SRSX25 $\quad 17.60$

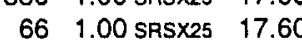

$0.00 \quad 0.480$

$\begin{array}{ll}35.00 & 1.000\end{array}$

$0.75 \quad 1.000$
0.00

$600.00 \quad 20.000$

$2,448 \quad 1.00$ SRSX25 $\quad 17.60$

$21,500 \quad 1.00$ SASX29 $\quad 15.10$

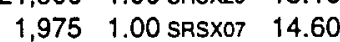

$\begin{array}{rrr}1,975 & 1.00 \text { SRSX07 } & 14.60 \\ 800 & 1.00 \text { SASX08 } & 17.30\end{array}$

$\begin{array}{lll}1,200 & 1.00 \text { SRSX } 10 & 12.20\end{array}$

$23,880 \quad 1.00$ SRSX07 $\quad 14.60$

$0.75 \quad 1.000$

$640 \quad 1.00$ SRSXOO $\quad 17.30$

27,528

52,500

8,125

SERVICES

$600.00 \quad 20.000$

$\begin{array}{lll}1,467 \quad 1.00 \text { SRSX10 } & 12.20\end{array}$

94,763
22,050

0
0
4,763
22,050
25,200
0

\begin{tabular}{rrrr}
32,240 & 9,516 & 0 & 41,756 \\
\hline$, 393,406$ & 496,238 & 562,000 & $2,991,643$ \\
& & & \\
0 & 0 & 400,000 & 400,000 \\
0 & 7,603 & 0 & $12,607,603$ \\
94,763 & 25,080 & 0 & 119,843 \\
22,050 & 10,384 & 0 & 32,434 \\
25,200 & 14,784 & 0 & 39,984 \\
0 & 0 & 0 & 0 \\
0 & 0 & 0 & 0 \\
213,725 & 69,388 & 0 & 283,113 \\
8,500 & 5,139 & 0 & 13,639 \\
9,800 & 7,216 & 0 & 17,016
\end{tabular}

\begin{tabular}{rrrr}
32,240 & 9,516 & 0 & 41,756 \\
\hline$, 393,406$ & 496,238 & 562,000 & $2,991,643$ \\
& & & \\
0 & 0 & 400,000 & 400,000 \\
0 & 7,603 & 0 & $12,607,603$ \\
94,763 & 25,080 & 0 & 119,843 \\
22,050 & 10,384 & 0 & 32,434 \\
25,200 & 14,784 & 0 & 39,984 \\
0 & 0 & 0 & 0 \\
0 & 0 & 0 & 0 \\
213,725 & 69,388 & 0 & 283,113 \\
8,500 & 5,139 & 0 & 13,639 \\
9,800 & 7,216 & 0 & 17,016
\end{tabular}

\begin{tabular}{rrrr}
32,240 & 9,516 & 0 & 41,756 \\
\hline$, 393,406$ & 496,238 & 562,000 & $2,991,643$ \\
& & & \\
0 & 0 & 400,000 & 400,000 \\
0 & 7,603 & 0 & $12,607,603$ \\
94,763 & 25,080 & 0 & 119,843 \\
22,050 & 10,384 & 0 & 32,434 \\
25,200 & 14,784 & 0 & 39,984 \\
0 & 0 & 0 & 0 \\
0 & 0 & 0 & 0 \\
213,725 & 69,388 & 0 & 283,113 \\
8,500 & 5,139 & 0 & 13,639 \\
9,800 & 7,216 & 0 & 17,016
\end{tabular}

$342.0 \mathrm{CY}$

$62.00 \quad 1.500$

$300.00 \quad 12.000$

$4,104 \quad 1.00$ sASX13 $\quad 16.20$

0

$\begin{array}{rr}213,725 & 69,388 \\ 8,500 & 5,139 \\ 9,800 & 7,216 \\ 12,480 & 5,812 \\ 124,000 & 1,162 \\ 0 & 43,085 \\ 752,500 & 324,650 \\ 1,481 & 28,835 \\ 24,000 & 13,840 \\ 49,600 & 14,640 \\ 17,910 & 348,648\end{array}$

283,113
13,639

17,016

18,292

125,162

43,085
077,150

$1,077,150$
30,316

37,840

64,240

366,558

30,272

78,533

WBS1.2.2.2 CASE 10 - OPTION \#2 SUBTOTAL

BUILDING FOR CHILLERS $\quad 12,000.0 \mathrm{SF}$ FORM WORK CHILL

66,485

169,085

$15,554,164$

$\begin{array}{ll}0.75 & 1.000\end{array}$

$\begin{array}{lll}1,200 & 1.00 \text { SASX07 } & 14.60\end{array}$
\end{abstract}

0
0

$, 015,720$

20,000
900

90,000
900

900

181,200
17,520

$\begin{array}{rr}400,000 & 15,554,164 \\ & ========= \\ 0 & 601,200 \\ 0 & 18,420\end{array}$


FILE: APTCOOI

PRoject NAME: PRUueCT NAME
ENGINEERING \& CONS JCTION SERVICES DIVISION

SITE PROJECT ESTIMATING

DETAIL LINE ITEMS
PAGE * 12

TIME: 08:35:58

DATE 09-Aug-1996

PRICING: PRE 95 OR POST 94 RATES

REPORT NAME: APT Detall WBS EXCEL FORMAT

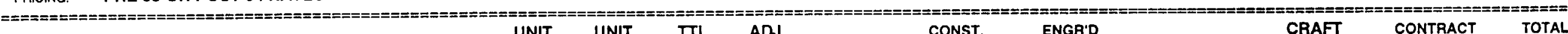

WBS TWC DESCRIPTION QUANTITY UOM MATL MHRS HOURS FACT CREW \$MH EQUIP. EQUIP.

CASE 10 - OPTION \#3

GROUP : NO APT GROUP IDENTIFIED ACCOUNT CODE:

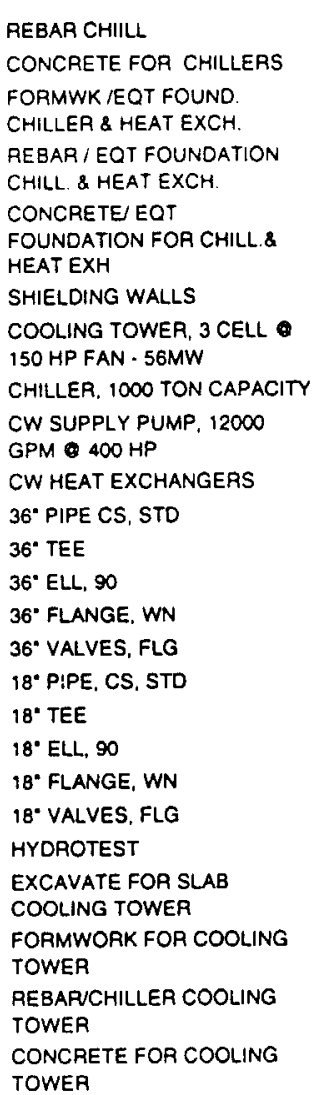

\begin{tabular}{rrr} 
& \multicolumn{2}{c}{ WBS 1.2 .2 .3} \\
$22.0 \mathrm{TN}$ & 600.00 & 20.000 \\
$444.0 \mathrm{CY}$ & 62.00 & 1.500 \\
$2,040.0 \mathrm{SF}$ & 0.75 & 1.000 \\
& & \\
$15.0 \mathrm{TN}$ & 600.00 & 20.000 \\
& & \\
$444.0 \mathrm{CY}$ & 62.00 & 1.500 \\
& & \\
$175.0 \mathrm{CY}$ & 300.00 & 12.000 \\
$1.0 \mathrm{EA}$ & 0.00 & 0.000 \\
& & \\
$2.0 \mathrm{EA}$ & 0.00 & 0.000 \\
$3.0 \mathrm{EA}$ & 180000.00 & 180.000 \\
& & \\
$2.0 \mathrm{EA}$ & 2100000.00 & 72.000 \\
$950.0 \mathrm{LF}$ & 99.75 & 1.500 \\
$10.0 \mathrm{EA}$ & 2205.00 & 59.000 \\
$20.0 \mathrm{EA}$ & 1260.00 & 42.000 \\
0.0 & & \\
0.0 & & \\
$4.150 .0 \mathrm{LF}$ & 51.50 & 0.950 \\
$10.0 \mathrm{EA}$ & 850.00 & 29.200 \\
$20.0 \mathrm{EA}$ & 490.00 & 20.500 \\
$26.0 \mathrm{EA}$ & 480.00 & 12.700 \\
$10.0 \mathrm{EA}$ & 12400.00 & 6.600 \\
$5,100.0 \mathrm{LF}$ & 0.00 & 0.480 \\
$500.0 \mathrm{CY}$ & 0.00 & 0.100 \\
$540.0 \mathrm{CY}$ & 0.75 & 1.000 \\
$26.0 \mathrm{TN}$ & 600.00 & 20.000 \\
$520.0 \mathrm{CY}$ & 62.00 & 1.500
\end{tabular}

WBS1.2.2.3 CASE 10 - OPTION \#3 SUBTOTAL

CHILLER, 1000 TON CAPACITY CW HEAT EXCHANGERS 36. PIPE CS. STD

$36^{\circ}$ TEE

$36^{\circ}$ ELL, 90

36. FLANGE, WN

36. VALVES, FLG

18. PIPE, CS, STO

\begin{tabular}{|c|c|c|}
\hline & CAS & E $10-$ \\
\hline 440 & 1.00 SRSXOB & 17.30 \\
\hline 666 & 1.00 SRS $\times 10$ & 12.20 \\
\hline 2,040 & 1.00 SRS $\times 07$ & 14.60 \\
\hline 300 & 1.00 SRS $\times 08$ & 17.30 \\
\hline 666 & 1.00 SRS $\times 10$ & 12.20 \\
\hline $\begin{array}{r}2,100 \\
0\end{array}$ & $\begin{array}{l}1.00 \text { SRS } \times 13 \\
1.00\end{array}$ & 16.20 \\
\hline 0 & 1.00 & \\
\hline 540 & 1.00 sRSX01 & 17.60 \\
\hline 144 & 1.00 SRSX01 & 17.60 \\
\hline 1,425 & $1.00 \mathrm{SRS} \times 25$ & 17.60 \\
\hline 590 & $1.00 \mathrm{SRS} \times 25$ & 17.60 \\
\hline 840 & 1.00 SRSX25 & 17.60 \\
\hline 0 & 1.00 SRS $\times 25$ & \\
\hline 0 & $1.00 \mathrm{SRS} \times 25$ & \\
\hline 3,943 & 1.00 SRSX25 & 17.60 \\
\hline 292 & 1.00 SRSK25 & 17.60 \\
\hline 410 & $1.00 \mathrm{SRS} \times 25$ & 17.60 \\
\hline 330 & 1.00 SASX25 & 17.60 \\
\hline 66 & 1.00 SRSX25 & 17.60 \\
\hline 2,448 & 1.00 SRSX25 & 17.60 \\
\hline 50 & 1.00 SRSX05 & 16.20 \\
\hline 540 & 1.00 SRS $\times 07$ & 14.60 \\
\hline 520 & 1.00 SAS $\times 08$ & 17.30 \\
\hline 780 & $1.00 \mathrm{SRS} \times 10$ & 12.20 \\
\hline
\end{tabular}

\begin{tabular}{|c|c|c|c|c|}
\hline 0 & 13,200 & 7,612 & 0 & 20,812 \\
\hline 0 & 27,528 & 8,125 & 0 & 35,653 \\
\hline 0 & 1,530 & 29,784 & 0 & 31,314 \\
\hline 0 & 9,000 & 5,190 & 0 & 14,190 \\
\hline 0 & 27,528 & 8,125 & 0 & 35,653 \\
\hline 0 & 52,500 & 34,020 & 0 & 86,520 \\
\hline 0 & 0 & 0 & 562,000 & 562,000 \\
\hline 0 & 0 & 0 & 400,000 & 400,000 \\
\hline 540,000 & 0 & 9,504 & 0 & 549,504 \\
\hline $4,200,000$ & 0 & 2,534 & 0 & $4,202,534$ \\
\hline 0 & 94,763 & 25,080 & 0 & 119,843 \\
\hline 0 & 22,050 & 10,384 & 0 & 32,434 \\
\hline 0 & 25,200 & 14,784 & 0 & 39,984 \\
\hline 0 & 0 & 0 & 0 & 0 \\
\hline 0 & 0 & 0 & 0 & 0 \\
\hline 0 & 213,725 & 69,388 & 0 & 283,113 \\
\hline 0 & 8,500 & 5,139 & 0 & 13,639 \\
\hline 0 & 9,800 & 7,216 & 0 & 17,016 \\
\hline 0 & 12,480 & 5,812 & 0 & 18,292 \\
\hline 0 & 124,000 & 1,162 & 0 & 125,162 \\
\hline 0 & 0 & 43,085 & 0 & 43,085 \\
\hline 0 & 0 & 810 & 0 & 810 \\
\hline 0 & 405 & 7,884 & 0 & 8,289 \\
\hline 0 & 15,600 & 8,996 & 0 & 24,596 \\
\hline 0 & 32,240 & 9,516 & 0 & 41,756 \\
\hline
\end{tabular}

COTAL

LABOR SERVICES COST


FILE: APTCOOI

PRoject Name: PROJECT NAME
ENGINEERING \& CONE JUIION SERVICES DIVISION

SITE PROJECT ESTIMATING

DETAIL LINE ITEMS
PAGE * 13

TIME: 08:35:58

DATE 09-Aug-1996

PAICING: PRE 95 OR POST 94 RATES

REPOAT NAME: APT Detail WBS EXCEL FORMAT

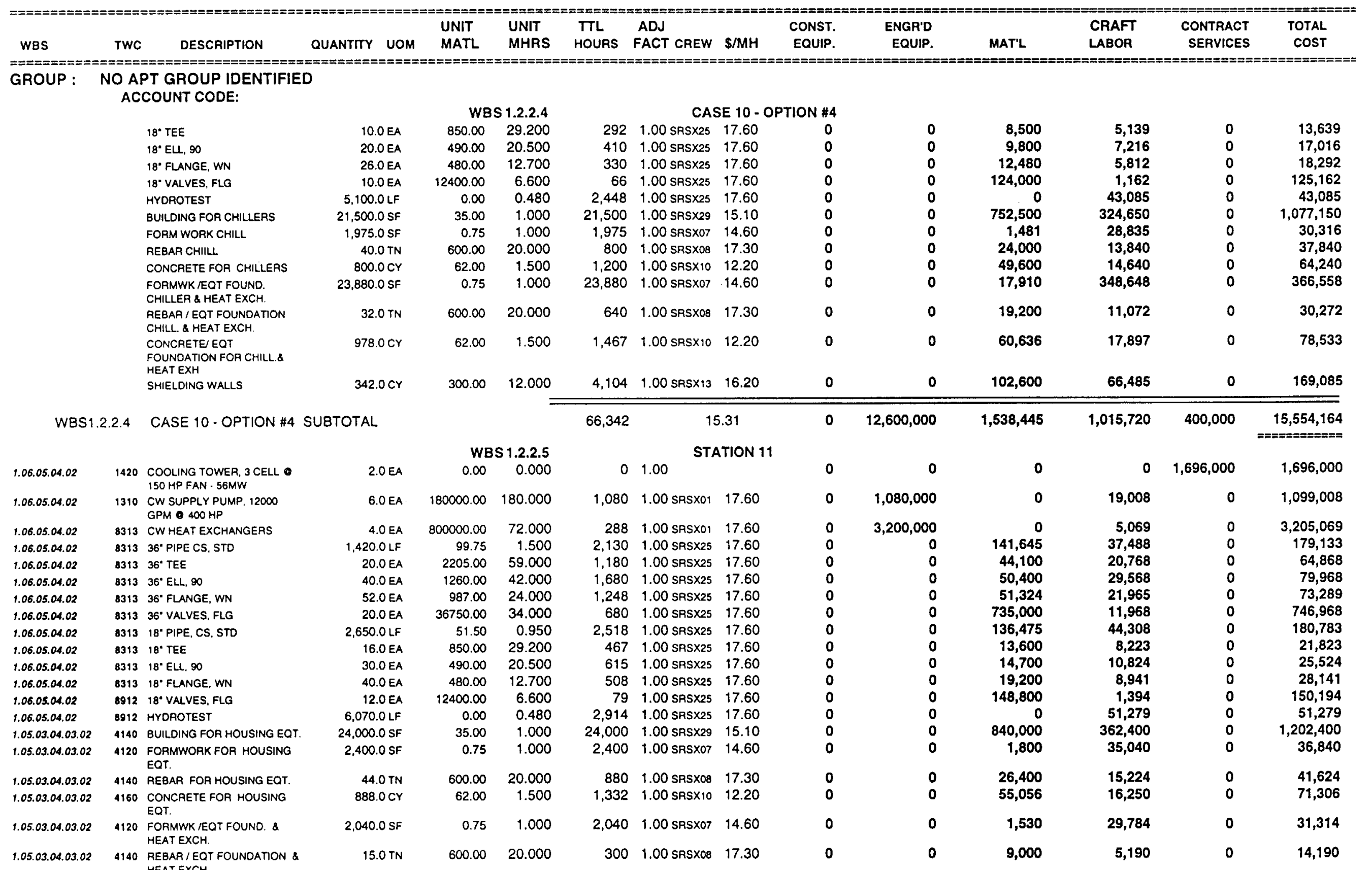


FILE: APTCOOI
PROJeCT NAME: PRUueCt NAME
ENGINEERING \& CONS JUTION SERVICES DIVISION

SITE PROJECT ESTIMATING

DETAIL LINE ITEMS
PAGE * 14

TIME: 08:35:58

DATE 09-Aug-1996

REPORT NAME: APT Detall WBS EXCEL FORMAT

PRICING: PRE 95 OR POST 94 RATES

UNIT UNIT TTL ADJ CONST

QUANTITY UOM MATL MHRS HOURS FACT CREW \$MH

TTL ADJ

EQUIP.

CRAFT

LABOR

CONTRACT

SERVICES

TOTAL

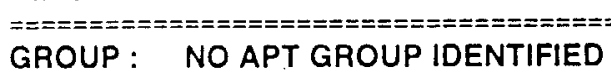
ACCOUNT CODE:

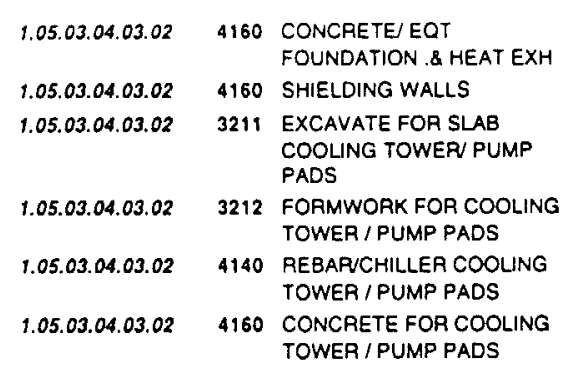

WBS1.2.2.5 STATION 11 SUBTOTAL

$\begin{array}{ll}\text { EXCAVATE HAZARDOUS OIRT } & 225,000.0 \mathrm{cY} \\ \text { BY MACHINE } & \\ \text { HAUL \& DUMP } & 225,000.0 \mathrm{cr} \\ \text { ASSUME THAT 50\% OF } & 112,500.0 \mathrm{cY} \\ \text { HAZARDOUS DIRT IS } & \\ \text { TREATED } & \\ \text { ASSUME THAT S0\% OF } & 112,500.0 \mathrm{cY} \\ \text { HAZARDOUS DIRT IS } & \\ \text { DISPOSED } & \\ \text { PURCHASE \& INSTALL CLEAN } & 225,000.0 \mathrm{cY} \\ \text { FILL COMMON BORROW } \\ \text { COMPACT COMMON BORROW }\end{array}$

$444.0 \mathrm{CY}$

WBS 1.2.2.5

$62.00 \quad 1.500$

$175.0 \mathrm{CY}$

$300.00 \quad 12.000$

$\begin{array}{lrr}800.0 \mathrm{Cr} & 0.00 \quad 0.100\end{array}$

$950.0 \mathrm{CY}$

$50.0 \mathrm{TN}$

$900.0 \mathrm{Cr}$

STATION 11

$2.100 \quad 1.00$ sasxis 16.20

0

0
0
0

MAT'L

$\begin{array}{rr}0 & 27,528 \\ 0 & 52,500 \\ 0 & 0\end{array}$

8,125

34,020

34,020
1,296

0

35,653

86,520
$0.75 \quad 1.000$

$600.00 \quad 20.000$

$62.00 \quad 1.500$

$\begin{array}{lll}80 & 1.00 \text { SRS } \times 05 & 16.20\end{array}$

$950 \quad 1.00$ SAS $\times 07 \quad 14.60$

$1.000 \quad 1.00$ SRSX08 $\quad 17.30$

$1,350 \quad 1.00 \mathrm{SRS} \times 10 \quad 12.20$

$\begin{array}{lll}1.500 & 1,350 \quad 1.00 \mathrm{SRS} \times 10 \quad 12.20\end{array}$

0
0
0

\begin{tabular}{|c|c|c|c|c|c|c|c|c|c|c|}
\hline & & 52,485 & & .73 & 0 & $4,280,000$ & $2,455,571$ & 825,772 & $1,696,000$ & $\begin{array}{r}9,257,342 \\
==========\end{array}$ \\
\hline \multicolumn{2}{|c|}{ WBS 1.2.5.1 } & \multicolumn{6}{|c|}{ ADDED SITE EXCAVATION } & \multirow[b]{2}{*}{174,960} & \multirow[b]{2}{*}{0} & \multirow[b]{2}{*}{381,960} \\
\hline 0.00 & 0.048 & 10,800 & 1.60 SRSX05 & 16.20 & 207,000 & 0 & 0 & & & \\
\hline 0.00 & 0.037 & 8,280 & $1.60 \mathrm{SRS} \times 05$ & 16.20 & $1,012,500$ & 0 & 0 & 134,136 & 0 & $1,146,636$ \\
\hline 0.00 & 0.000 & 0 & 1.00 & & 0 & 0 & 0 & 0 & $\because, \cdots, * * *$ & $33,750,000$ \\
\hline 0.00 & 0.000 & 0 & 1.00 & & 0 & 0 & 0 & 0 & $*,+\cdots+, \cdots$ & $16,875,000$ \\
\hline 3.64 & 0.023 & 5,175 & 1.00 SASX05 & 16.20 & 321,750 & 0 & 819,000 & 83,835 & 0 & $1,224,585$ \\
\hline \multirow[t]{5}{*}{0.00} & 0.007 & 1,575 & 1.00 SRSX05 & 16.20 & 45,000 & 0 & 0 & 25,515 & 0 & 70,515 \\
\hline & & 25,830 & \multicolumn{2}{|c|}{16.20} & $1,586,250$ & 0 & 819,000 & 418,446 & $50,625,000$ & $\begin{array}{r}53,448,696 \\
==x=======\end{array}$ \\
\hline & \multicolumn{2}{|c|}{ 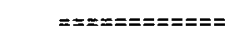 } & \multicolumn{3}{|c|}{ 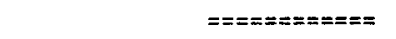 } & 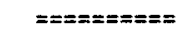 & $==\Xi===== \pm====$ & \multicolumn{2}{|c|}{ 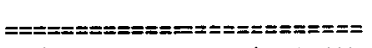 } & \multirow{2}{*}{$\begin{array}{l}========= \pm \\
\$ 230,664,876 \\
===========\end{array}$} \\
\hline & \multicolumn{2}{|c|}{$2,183,049$} & 16.47 & \multicolumn{2}{|c|}{$\$ 3,448,300$} & $\$ 128,149,488$ & $\$ 12,172,940$ & $\$ 35,959,148$ & $\$^{*}, * * *, \ldots * *$ & \\
\hline & \multicolumn{2}{|c|}{$2,183,049$} & \multicolumn{3}{|r|}{$3,448,300$} & $128,149,488$ & $12,172,940$ & $35,959,148$ & $50,935,000$ & $230,664,876$ \\
\hline
\end{tabular}

13,870

17,300

$0 \quad 30,000$

713
30,000

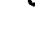

NO APT GROUP IDENTIFIED GROUP SUBTOTAL

SITE \#2, COOLING OPTION \#1 ACCOUNT CODE: BO2110 STRUCTURES AND IMPROVEMENTS

GROUP : BALANCE OF PLANT

WBS 1.2.1.01

3211 MACHINE EXCAVATE FOR $\quad 17,174.0 \mathrm{CY} \quad 0.00 \quad 0.030$ SITE 2 OPTION 1

3212 HAND EXCAVATE FOR SITE 2

$5,725.0 \mathrm{CY}$ OPTION 1

3221 FURNISH \& PLACE PIPE BEDDING SAND

$5,725.0 \mathrm{Cr}$

$0.00 \quad 4.000$

3221 TRENCH BACKFILL

$18,497.0 \mathrm{Cr}$

$8.00 \quad 0.830$

$0.00 \quad 0.060$

(2)
COMPACTION

\begin{tabular}{rrrr} 
& \multicolumn{3}{c}{ SITE \#2, COOLING OPTION \#1 } \\
515 & 1.00 SRSX05 & 16.20 & 15,800 \\
22,900 & 1.00 SRSX04 & 11.80 & 0 \\
2,013 & 1.00 SRSX04 & 11.80 & 0 \\
1,110 & 1.00 SRSX05 & 16.20 & 15,168
\end{tabular}

0
0
0

$\begin{array}{rr}0 & 8,347 \\ 0 & 270,220 \\ 19,400 & 23,750 \\ 0 & 17,979\end{array}$

0
0
0
0

24,147
270,220
43,150
33,147 
FILE: APTCOOI

pRoject Name: PRCuect NAME

PRICING: PRE 95 OR POST 94 RATES

WBS TWC DESCRIPTION

QUANTTY UOM MATL

MATL MHRS

FACT CREW $\$$ SMH

$=================$

GROUP: BALANCE OF PLANT

ACCOUNT CODE: BO2110 STRUCTURES AND IMPROVEMENTS

WBS 1.2.1.01

3216 HAUL \& DUMP (EXCESS)

$5,091.0 \mathrm{Cr}$

$0.00 \quad 1.200$

SITE \#2, COOLING OPTION \#1

WBS1.2.1.01 SITE \#2, COOLING OPTION \#1 SUBTOTAL

$200 \quad 6.109 \quad 1.00$ SRSX05 16.20

0

0

$\begin{array}{llll}32,647 & 12.84 & 30,968 & 0\end{array}$

WBS 1.2.1.05 SITE \#8, COOLING OPTION \#1

3211 MACHINE EXCAVATE FOR

$30,174.0 \mathrm{cr} \quad 0.00 \quad 0.030$

$905 \quad 1.00$ SRSX05 $\quad 16.20$

27,760

$10.059 .0 \mathrm{CY}$

$3,792.0 \mathrm{CY}$

2 MAND EXCAVA
OPTION 1

$0.00 \quad 4.000$

$40,236 \quad 1.00$ SRSX04 $\quad 11.80$

$3,147 \quad 1.00$ SRSX04 $\quad 11.80$

FURNISH \& PLACE PIPE

3229 TRENCH BACKFILL \&

COMPACTION

$32,245.0 \mathrm{CY}$

$10,661.0 \mathrm{CY}$

3216 HAUL \& DUMP (EXCESS)

WBS 1.2.1.05 SITE \#8, COOLING OPTION \#1 SUBTOTAL

$0.00 \quad 0.060$

$1,935 \quad 1.00$ SASX05 16.20

0

0

26,441

$0.00 \quad 1.200$

\begin{tabular}{ll}
$12,793 \quad 1.00$ SRS $\times 05 \quad 16.20$ \\
\hline
\end{tabular}

0

$\begin{array}{lll}59,016 & 12.97 & \mathbf{5 4 , 2 0 1}\end{array}$

91,663

12.92

$==\geq= \pm======$
$\$ 85,169$

12.92

85,169

0

49,736

TIME. $08 \cdot 35: 58$

DATE 09-Aug-1996

REPORT NAME: APT Detail WES EXCEL FORMAT

(CRAFT

CRAFT CONTRACT TOTAL

BALANCE OF PLANT GROUP SUBTOTAL

(1)


.TCOOL

.cTT NAME: PRUuECT NAME
ENGINEERING \& CONS JCTION SERVICES DIVISION

SITE PROJECT ESTIMATING

DETAIL LINE ITEMS
PAGE * 16

TIME: 08:35:58

OATE 09-Aug-1996

REPORT NAME: APT Detall WBS EXCEL FORMAT

PRICING: PRE 95 OR POST 94 RATES

(UTH

UNIT UNIT TTL ADJ $\quad$ CONST. ENGR'D

QUANTITY UOM MATL

HOURS FACT CREW \$MH EQUIP.

EQUIP.

MATL

CRAF

LABOR

CONTRACT SERVICES

TOTAL COST

\section{PROJECT SUBTOTAL}

PROJECT ESCALATION

PROJECT SUBTOTAL INCLUDING ESCALATION

SUBTOTAL INCLUDING ESCALATION

MANAGEMENT RESERVE @ $0.00 \%$

CONTINGENCY $0.00 \%$

CONTINGENCY NOTE:

PROJECT TOTAL COST
$2,274,712 \quad 16.33$

33

$\$ 3,533,469$

\section{$\$ 0$}

$2,274,712$

$16.33^{2=}$

$3_{z== \pm=}^{s= \pm== \pm}$

$\$ 3,533,469$

$\$ 128,149,488$
$\$ 128$

$\$ 0$

\$o

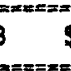

$2,274,712 \quad 16.33^{=}$

$\$ 3,533,469$

$\$ 128,149,488$

$\$ 12,222,676$

$\$ 37,143,594 \quad \$ 50,935,000$
$\$ 37,143,594$

So

\$o
$\$ 0$ 